\title{
SECUENCIA ESTRATIGRÁFICA TARTESIA Y TURDETANA DE VICO (MARCHENA, SEVILLA)
}

\section{THE TARTESSIAN AND TURDETANIAN STRATIGRAPHIC SEQUENCE OF VICO (MARCHENA, SEVILLA)}

\author{
por \\ MARÍA LUISA DE LA BANDERA ROMERO Y \\ EDUARDO FERRER ALBELDA ${ }^{1}$
}

RESUMEN En homenaje al Prof. Pellicer presentamos los resultados de una excavación arqueológica de urgencia llevada a cabo en el yacimiento de Vico (Marchena, Sevilla). Se trata de un tell artificial que forma parte del conjunto arqueológico de Montemolín y que constituye el núcleo principal de habitación durante una secuencia cronológica ininterrumpida que abarca cerca de un milenio, desde al menos el período orientalizante hasta época imperial romana.

In these papers offerings to Prof. Pellicer we present the study of an urgence archeological
excavation of Vico's site (Marchena, Sevilla). It is a tell inside of a bigger settlement called
Montemolín, and it's the settlement during the orientalizang period to imperial roman occupation.

Palabras claves Asentamiento. Tartesio. Turdetano. Secuencia estratigráfica.

Key words $\quad$ Settlement. Tartesian. Turdetanian. Stratigraphic secuence.

\section{INTRODUCCIÓN}

La contribución del profesor Pellicer Catalán a la vertebración de los estudios protohistóricos en el Bajo Guadalquivir, aunque no lo suficientemente valorada, ha sido decisiva para la configuración de un marco cronológico y geográfico a partir del cual la investigación posterior ha podido discurrir por unos cauces

1. Departamento de Prehistoria y Arqueología. Facultad de Geografía e Historia. Universidad de Sevilla. Este trabajo se encuadra en el marco del Proyecto La formación de la Bética romana, incluido en el II Plan de Investigación de la Junta de Andalucía (HUM152) y en el Plan General de Promoción del Conocimiento (DGES PB-97-0736). 
bien delimitados, que se mantienen aún vigentes en sus principales formulaciones. Una revisión del estado de la investigación previo a los trabajos de Pellicer deja patente el contraste entre el antes y el después de su contribución (Pellicer 1982: 307-313; id. 1995), y no nos referimos solamente a una valoración cuantitativa de su obra, sino, ante todo, cualitativa.

Esta formulación no fue fruto de la improvisación ni de la intuición sino que se cimentó sobre unas bases metodológicas rigurosas que, aunque ajenas en cierta medida a los avances de la metodología arqueológica española en las tres últimas décadas, siguen hoy plenamente vigentes e incorporadas a la mayoría de los proyectos de investigación. Mantenía el prof. Pellicer que los pilares de la Historia son la geografía y la cronología, las coordenadas espacio-temporales, de manera que es en estos dos aspectos donde debían concentrarse los esfuerzos de la investigación. La coordenada espacial se pretendió cubrir con la elaboración de Cartas Arqueológicas en forma de Tesis de Licenciatura bajo su dirección, algunas de las cuales fueron publicadas, aunque la mayoría permanece inédita (Pellicer 1989: 159). Sin embargo, toda esta documentación nunca se sistematizó y los resultados, salvo la excepción de Los Alcores (Amores 1979-80 y 1982; Amores y Rodríguez Temiño 1984), fueron pobres y, en líneas generales, desaprovechados.

La coordenada temporal mereció más dedicación personal y en consecuencia dio mejores resultados. Las bases cronológicas las estableció mediante la excavación de asentamientos de primer orden con secuencias estratigráficas que abarcaban la mayor parte del I ${ }^{\mathrm{er}}$ milenio a.C., lo que permitía establecer fenómenos de convergencia (la estratigrafía comparada) con otros yacimientos excavados antiguamente, y con asentamientos con estratigrafías menos completas. Teniendo como antecedentes las secuencias de Carmona, Cerro del Real, Colina de los Quemados, Ategua y Huelva, inauguró un período en la segunda mitad de la década de los setenta y en los primeros años ochenta en el que la nómina de yacimientos excavados aumentó considerablemente ${ }^{2}$, y quedó más o menos perfilada la periodización del I ${ }^{\text {er }}$ milenio a.C. y su caracterización arqueológica.

Las líneas marcadas en su artículo "Ensayo de periodización y cronología tartesia y turdetana" (Pellicer 1982: 324 ss.) han prevalecido hasta la actualidad sin grandes modificaciones tanto en los aspectos conceptuales como en los terminológicos. Entre éstos y aquéllos podemos destacar la progresiva sustitución del término "ibérico" con valor cronológico y étnico por el de "turdetano", o la consideración de Tartessos como una cultura limitada geográficamente al valle del Guadalquivir y Huelva, con unos orígenes rastreables en el Bronce Final del Suroeste. Por tanto se puede hablar de un período tartésico precolonial (Pellicer 1989 y 1992) y de su continuación colonial u orientalizante (Pellicer 1983 y 2000), y seguidamente de un período turdetano.

Es preciso aclarar que esta lectura es esencialmente arqueológica, es decir, que a unos términos utilizados en la literatura grecolatina-tartesio y turdetano-se les ha otorgado un contenido arqueográfico, pues ambos etnónimos designan en realidad a un mismo pueblo. La división entre tartesios y turdetanos, como ocurre entre fenicios y púnicos, es el resultado de una interpretación antigua -doble trascripción de un mismo etnónimo-(García Moreno 1989; García Fernándeze.p.) ${ }^{3}$, y de una convención arqueológica reciente que pretende resaltar las evidentes transformaciones operadas entre un período de tiempo y otro, también conocidos como primera y segunda Edad del Hierro.

Sobre esta base han descansado los trabajos de síntesis más recientes, cuyos objetivos se han encaminado al análisis de aspectos concretos de la problemática tartesia-turdetanả, como la cuestión del horizonte fundacional de los asentamientos tartésicos (Escacena y Belén 1991; Belén, Escacena y Bozzino 1992),

2. A mediados de los setenta Pellicer excavó en Cerro Macareno (Pellicer y otros 1983); la secuencia estratigráfica de este yacimiento sirvió como modelo para posteriores excavaciones. A Cerro Macareno le siguieron en el tiempo nuevas campañas de excavaciones en Alhonoz, Huelva y Ategua, y las de Mesa de Setefilla, Lebrija, Montemolín, Llanete de los Moros, El Gandul, Cerro de la Cabeza, Sevilla, etc. (Pellicer 1989: 154-155).

3. Ver en este mismo volumen el artículo de F.J. García Fernández. 
la transición entre ambos períodos (Escacena 1993) o la caracterización de las comunidades turdetanas (Escacena 1989 y 1992; Escacena y Belén 1997; Belén y Escacena 1997).

Nuestra contribución en este volumen irá en la línea de los estudios secuenciales de los años 80 , presentando los resultados de una excavación de urgencia llevada a cabo en 1985 en el yacimiento arqueológico de Vico (Marchena, Sevilla), de la que sólo se publicó un escueto informe (Chaves y Bandera 1987). Sirvan estas líneas para expresar nuestra adhesión sincera a este merecido homenaje que el Departamento de Prehistoria y Arqueología de la Universidad de Sevilla rinde a la labor investigadora y docente del profesor Pellicer.

\section{EL YACIMIENTO ARQUEOLÓGICO DE VICO (MARCHENA, SEVILLA)}

\subsection{Descripción del yacimiento}

Situado a orillas del río Corbones, Vico es un tell de formación antrópica en su mayor parte, constituido sobre una elevación en la ladera noroeste del cerro de Montemolín, del que queda separado por una vaguada (fig. 1). Se trata en realidad de dos sectores de un mismo yacimiento arqueológico que, como veremos, constituyeron una sola entidad poblacional durante la mayor parte del $\mathrm{I}^{\mathrm{er}}$ milenio a.C. (Bandera y otros 1995: fig. 1.1). Por tanto, Vico comparte las mismas características físicas y geoestratégicas de Montemolín (visibilidad, cruce de vías de comunicación, fertilidad, etc.), en las que no insistiremos (Chaves y otros 1993; Bandera y otros 1994).

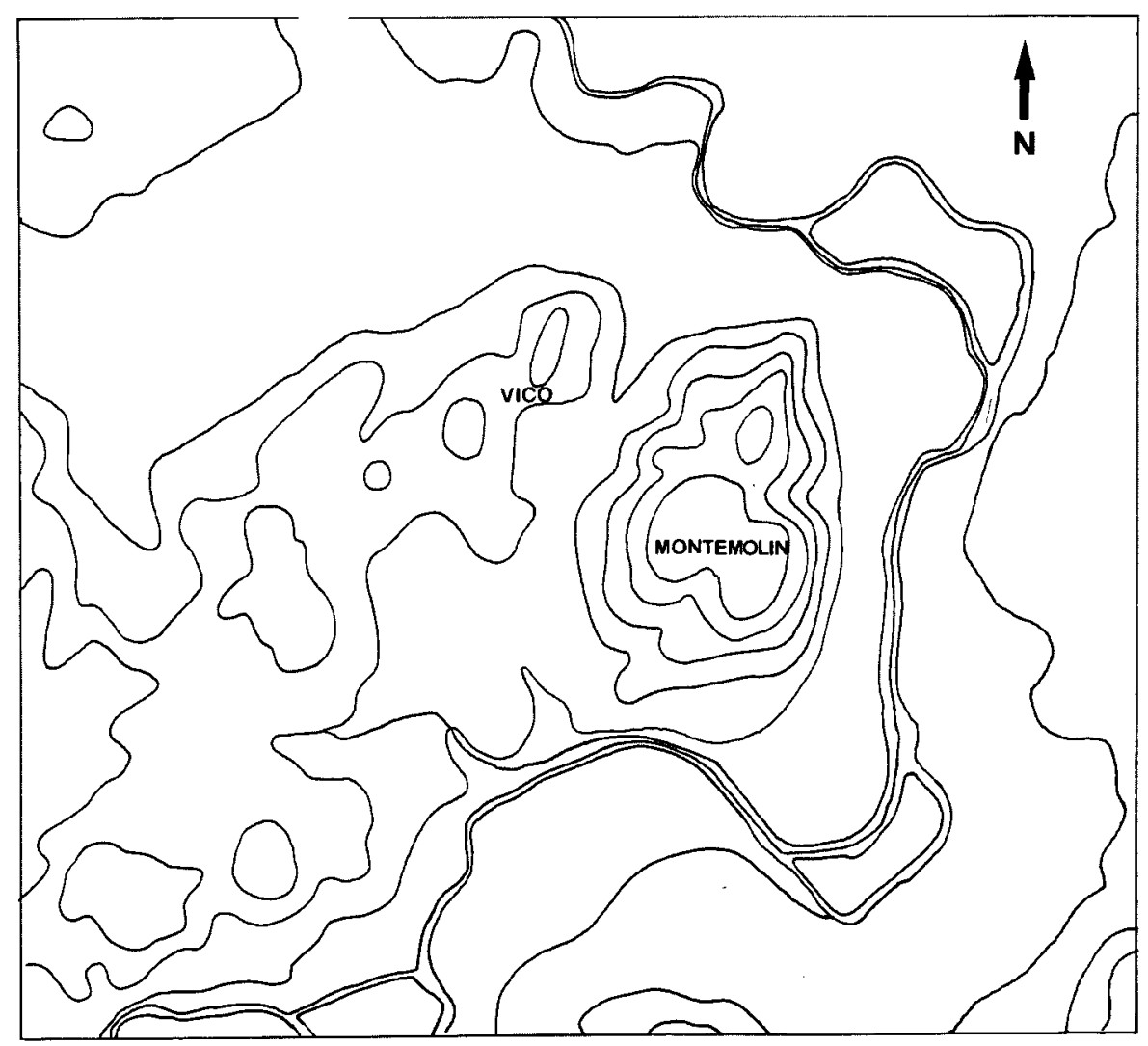

Fig. 1: Situación y plano de Vico (Marchena, Sevilla) 
La excavación de urgencia se programó cuando ya se habían llevado a cabo en Montemolín tres campañas arqueológicas (1980, 1981 y 1983) y se estaba desarrollando una cuarta (1985); y el motivo se debió a la destrucción a la que este sector estaba siendo sometido por la retirada de toneladas de piedras de su superficie (Chaves y Bandera 1987: 372). Estas labores de acarreo debieron eliminar la mayor parte de los vestigios del asentamiento romano, del que quedaba constancia por los fragmentos cerámicos (campaniense, Terra Sigillata Galica e Hispanica), material de construcción y restos de opus caementicium dispersos por la superficie, pues en la excavación no se apreciaron construcciones ni estratos claramente adscritos a este horizonte, tan sólo restos dispersos en estratos muy alterados.

De la desaparición de los contextos de época romana queda constancia por el contraste con las descripciones realizadas en los años 50 por Collantes de Terán, en las que se mencionan una estructura de opus caementicium, gran cantidad de terra sigillata, tegulae, ladrillos, mampuestos, laterculi, cerámica común y pesas de telar (Ordóñez 1996: 51), restos de los que apenas ya quedaban vestigios en 1985.

\subsection{La secuencia estratigráfica del corte A (fig. 2)}

El desmonte de los estratos romanos había dejado prácticamente en la superficie los contextos protohistóricos, que se suceden hasta casi los seis metros, profundidad a partir de la cual se abandonó la excavación por motivos de seguridad y por la falta de espacio, sin que se registrara la potencia estratigráfica completa del sector.

En la metodología de excavación se aplicó el “método Wheeler”, el habitual en aquellos años. Se planteó un corte de pequeñas dimensiones $(3 \times 3 \mathrm{~m})$ en la cima de tell y se procedió a la excavación mediante niveles artificiales, cambiándose la numeración a una profundidad determinada $(20-30 \mathrm{~cm})$, o según fueran apareciendo estructuras o cambios evidentes en la composición de los estratos, de manera que el número de niveles artificiales es superior al de estratos naturales, pues un solo estrato, sobre todo si es potente, daba lugar a varios niveles artificiales.

En la exposición de los resultados seguiremos el orden inverso de la excavación, o sea el real en las fases constructivas y en los procesos de deposición de los sedimentos. Hay que aclarar que, aunque los muros exhumados una vez registrados eran desmontados conforme se excavaba, fue preciso conservar algunos de éstos y por ello, a partir del nivel A-16, se redujo la superficie de excavación a pocos metros cuadrados.

El último contexto documentado es una plataforma de tendencia circular hecha de grandes piedras planas de roca caliza en el sector suroeste del corte (A-35, estrato I), que sirvió de cimiento a una cabaña de tendencia circular con alzado de adobes (muro 1, fig. 3). El diámetro interno de la estructura era aproximadamente de unos dos metros, y los paramentos tenían una anchura de unos $30 \mathrm{~cm}$. El interior de las paredes estaba revocado y una fina capa de greda blanquecina hacía de pavimento. La cabaña fue cubierta por un estrato (II o A-34 a A-31) de unos $25 \mathrm{~cm}$ de potencia compuesto básicamente por tierra quemada, carbones, trozos de adobes, piedras sueltas y fragmentos cerámicos.

La siguiente fase constructiva está definida por un murete rectilíneo de mampuestos de unos $24 \mathrm{~cm}$ de anchura y unos $67 \mathrm{~cm}$ de longitud que delimita un espacio mal definido en el ángulo SE del corte, pero identificable por el suelo de tierra apisonada endurecida por la acción del fuego. El potente estrato que cubre la construcción (A-30 a A-28 o III) está constituido por los derrumbes de ésta y por los rellenos acumulados, lo cual explica su composición heterogénea: margas, adobes, tierras de color amarillento y rojizo, escaso material cerámico, etc.

Este estrato está sellado por un pavimento de tierra apisonada (A-27c o IV), que debió pertenecer al interior de un edificio; sobre él se depositó un nivel potente de incendio (A-27b o V), compuesto por tierra quemada, carbones, restos de adobes y gran cantidad de cerámica, y cubierto a su vez por otro pavimento 
de arcilla rojiza que se extiende por toda la superficie (A-27a o VI). Este suelo inaugura una nueva fase edilicia presidida por la edificación de una construcción de muros rectos de la que sólo se documentó un muro perimetral con dirección este-oeste que abarca toda la anchura del corte (fig. 4). El paramento (muro 2) conservaba sólo dos hiladas de altura y un murete de división interna, y estaba construido sin fosa de cimentación, directamente sobre el suelo, mediante dos líneas de piedras careadas que delimitaban las caras exteriores. En la cara interior del muro aparece una línea de piedras paralela que puede responder al derrumbe del muro (fig. 4); el espacio entre éstas y el muro estaba relleno por sedimento de coloración rojiza que contenía fragmentos cerámicos (A-27 entre piedras de muro o VIIb).

Los estratos que cubren este edificio (A-26 o VII; A-25 y A-24 u VIII) se formaron por los desechos de habitación, por el derrumbe del mismo, y por la sedimentación natural y los rellenos aportados en la nivelación de la siguiente fase constructiva. Su composición es, por tanto, muy heterogénea, con abundantes restos de cenizas, cerámicas quemadas, restos óseos, terrones de margas verdosas, piedras sueltas, manchas de tierra rojiza y de albero, contenidos en un paquete de tierra de color marrón muy apelmazada.

Un proceso deposicional similar al de fases anteriores se reprodujo nuevamente: un pavimento de tierra apisonada (A-23b o IX) selló el estrato anterior e inauguraba una nueva fase, de la que no se conservan restos constructivos, tan sólo dos capas sucesivas (A-23a o X y A-22 u XI) que cubren el suelo, cuya composición sugiere su formación por actividades de habitación o por la acumulación de basuras: numerosos restos óseos, caracoles, cenizas y tierra quemada, muchos fragmentos de recipientes cerámicos, restos de adobes, etc.

Posiblemente sobre este estrato se levantó un edificio de grandes dimensiones a juzgar por las medidas de uno de los muros perimetrales registrados: $320 \mathrm{~cm}$ de longitud conservada, 112 de anchura y una altura del zócalo de piedras cercana a los $90 \mathrm{~cm}$ (muro 3; fig. 5). Está hecho con piedras de pequeño y mediano tamaño trabadas con barro y no se ha documentado zanja de cimentación. Las dimensiones de este muro y la necesidad de escalonar el corte para facilitar el trabajo de excavación hicieron que el espacio quedase reducido a menos de la mitad de la superficie del corte desde el nivel A-16, cuando el paramento aflora en superficie. 


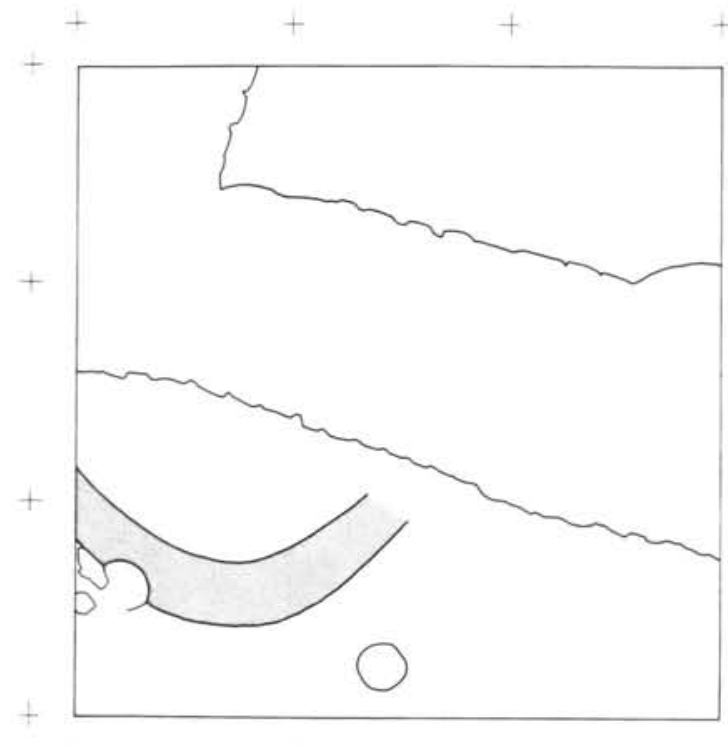

Fig. 3. Cabaña (muro 1, nivel A-35).

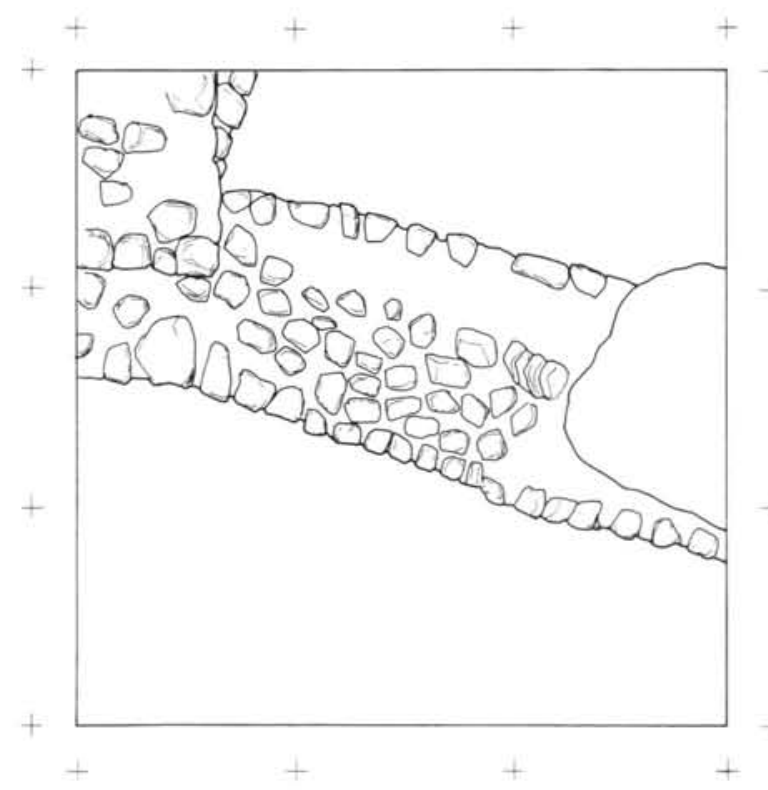

Fig. 5. Muro 3.

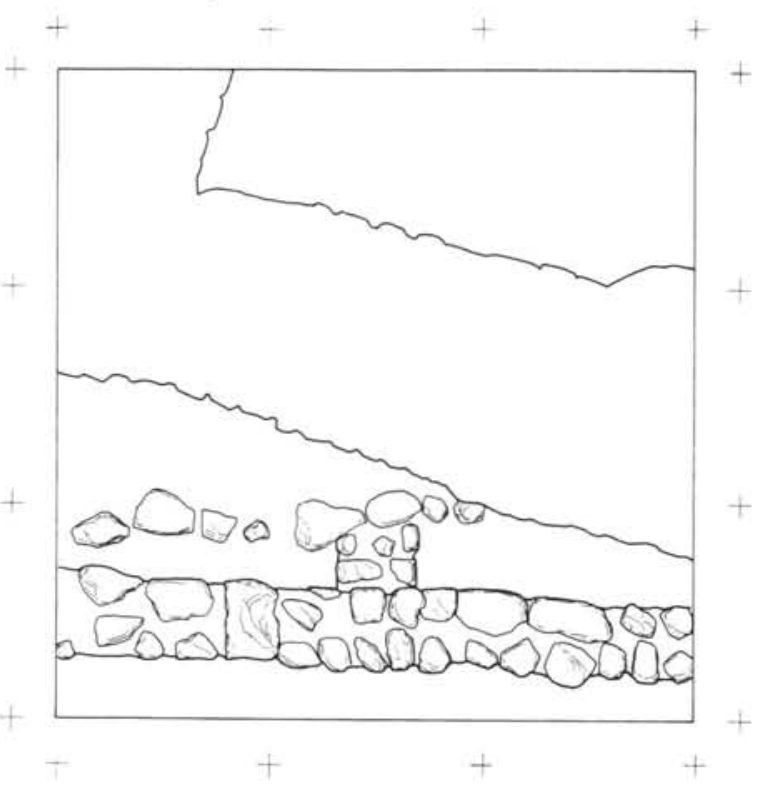

Fig. 4. Muro 2.

El espacio comprendido entre este muro y el perfil sur del corte será ocupado por una nueva construcción (muro 4), casi paralela a la anterior, pero posterior y posiblemente coetánea durante un tiempo, definida por muros unidos en ángulo recto, hechos con mampuestos, de unos $80 \mathrm{~cm}$ de anchura y $170 \mathrm{~cm}$ de longitud conservada. En la construcción del muro se utilizaron piedras de mediano tamaño y un gran sillar $(100 \times 55 \times 25 \mathrm{~cm})$. El estrato que rellena el interior del edificio (A-21 y A-20 o XII) está constituido por piedras sueltas, probablemente del derrumbe de la construcción, cerámicas y restos de fuego. Ambos, estrato y muro, quedaron a su vez cubiertos por un suelo apisonado de coloración rojiza (A-19b o XIII) sobre el que se registraron muchos fragmentos de recipientes cerámicos aplastados contra el pavimento, entre ellos varias ánforas, en un aglomerado de tierra quemada, cenizas, carbones y piedras sueltas (A-19a o XIV), sellado nuevamente por un suelo de adobe muy cuidado y de gran dureza (A-18b o XV). No conocemos bien la relación estratigráfica entre este pavimento y el muro 3, aunque es evidente que el primero es posterior al segundo porque lo cubre, pero no sabemos con certeza si todavía es el suelo interno o externo de este gran edificio. 
Sobre el pavimento de adobe sedimentó un estrato (A-18a o XVI) de tierra apelmazada, con fragmentos de cerámica, restos de adobes y pellas de arcilla con huellas vegetales, quizás del revestimiento de las paredes o de la techumbre. También se registró una piedra de molino, pero en el otro lado del muro (norte o XVII). A-18a fue cubierto por un nivel de habitación (A-17s o XVIII) integrado por una gran cantidad de recipientes cerámicos, sobre todo ánforas, restos de tierra quemada y de adobe, piedras sueltas, etc.

Una nueva construcción (muro 5) se documentó en una mínima parte, concretamente su ángulo sureste, en la esquina noroeste del corte. Como las restantes, está realizada con piedras de mediano tamaño trabadas con barro. El estrato que sedimenta en el exterior y sobre esta estructura, una vez amortizada ésta (A-14 a A-16 o XIX), estaba constituido por tierra de coloración rojiza, con muchos fragmentos cerámicos, sobre todo de ánforas, piedras sueltas, carbones, fragmentos de ocre y arena.

De la última fase constructiva registrada sólo se conservó los restos de un muro derruido que solo mantenía una hilada de piedras medianas trabadas con tierra y piedras pequeñas, y su zanja de cimentación (A-11 zanja de muro o XXI), bien delimitada por su coloración rojiza. La dirección del muro, noroeste-sureste, mantiene la misma orientación de los edificios anteriores. Esta zanja cortó un estrato (A-13, A-12s y A-11s o XX) formado por sedimento de color marrón y ceniciento, con mucho material cerámico y restos óseos y de carbón. En el sector noreste del corte se distinguió otro estrato que presentaba en su composición mayor cantidad de cenizas y carbones y se signó como A-11n y A-12n (XXII).

El estrato A-10 (XXIII) se deposita sobre los restos de la construcción y es cubierto a su vez por un suelo de guijarros y arena de gran potencia (más de $20 \mathrm{~cm}$ ) que ocupa las tres cuartas partes del corte ( $9 \mathrm{~b}$ o XXIV), describiendo una diagonal de dirección noroeste-sureste. En el centro del corte se detectó una torta de forma circular hecha de adobes. El sector que no tiene guijarros se signa como A-9a (o XXV). Ambos estratos son cubiertos a su vez por otro estrato signado como A-9 (XXVI).

Desde el nivel A-8 hasta la superficie no hay ninguna fase constructiva, y los estratos están alterados, ya que junto a los depósitos homogéneos de cerámicas turdetanas se registran esporádicamente intrusiones de cerámica (Terra Sigillata) y material constructivo (tegulae, estuco, opus caementicium) de época romana, ocasionales en las capas más profundas y en aumento a medida que nos acercamos a la superficie. Este fenómeno puede ser explicado por la acción de los arados subsoladores, cuyas rejas penetran en la tierra cerca de un metro, lo que hace posible que cerámicas y otros elementos de la superficie se depositen en los estratos más profundos. A pesar de ello, los niveles A-8 y A-7, salvo dos intrusiones, muestran indicios de escasa alteración; es un estrato de formación antrópica (XXVII), con restos de habitación, basuras y quizás derrumbes: restos óseos y de carbón, fragmentos cerámicos muy abundantes, sobre todo de ánforas, restos de adobe, etc.

Los niveles A-6 y A-5 (XXVIII) presentan restos de un hogar muy destruido, abundantes piedras quemadas y restos de carbón, gran cantidad de fragmentos cerámicos, restos óseos, almejas y caracoles, y trozos de adobe, integrados en un estrato de tierra cenicienta, indicios claros de una fase de incendio. En el resto de los niveles (A-4 a A-sup o XXIX) se registran mayores alteraciones y un progresivo incremento de los materiales de época romana.

\section{ESTRATIGRAFÍA COMPARADA}

La secuencia estratigráfica descrita presenta los rasgos característicos de un poblado tartesio-turdetano con una secuencia muy dinámica, característica de los sectores de habitación, lo que se evidencia en el número de fases constructivas registrado, once al menos si contamos tres pavimentos que no tenían relación directa con muros pero debían pertenecer a pavimentos de patios o al interior de edificios, o bien presentan signos del derrumbe de estructuras (A-27c, A-9b, A-6).

Desde el punto de vista de la ordenación del espacio, lo reducido del área excavada no permite hacer muchas conjeturas. Se documenta, eso sí, la sustitución del tipo de cabaña de planta circular o elíptica por 
construcciones de muros rectos, como se ha advertido en otro sector del yacimiento (Chaves y Bandera 1991; Bandera y otros 1994) y en otros poblados tartésicos coetáneos (Aguayo y otros 1986). Asimismo se puede hablar de una tendencia conservadora en las fases constructivas intermedias de la secuencia en lo que se refiere a la orientación de las edificaciones (este-oeste), calificativo que también pueden ser aplicado a las técnicas edilicias, a los contextos descritos (restos de habitación, basura), que hablan a favor de la continuidad en la funcionalidad de los espacios, y a la vajilla cerámica, que evoluciona de forma muy gradual desde fines del siglo VII a.C. hasta principios del siglo II a.C., que es el lapso de tiempo registrado en la estratigrafía.

Con respecto a la cronología de la secuencia, hemos utilizado la estratigrafía comparada como método de datación relativa de los contextos arqueológicos, dando por válido que los items arqueológicos, en concreto los recipientes cerámicos, tienen un período de fabricación y uso mejor o peor definido en el tiempo pero determinado, de manera que estos contextos pueden ser fechados relativamente teniendo presentes la totalidad de los items registrados en él y las circunstancias de formación del contexto.

En este sentido la estratigrafía de Vico presenta concomitancias con otras secuencias de asentamientos del Bajo Guadalquivir, especialmente con la de Cerro Macareno (Pellicer y otros 1983), que pasa por ser una secuencia paradigmática del $\mathrm{I}^{\mathrm{er}}$ milenio a.C. y, sin duda, la mejor documentada. Asimismo, también se pueden establecer comparaciones con otras secuencias estratigráficas menos completas como las de Carmona, Montemolín, Cerro de la Cabeza, Lebrija, Sevilla, Setefilla, Alhonoz, Ategua, Tejada, Huelva, Niebla y Colina de los Quemados.

Los estratos I a VIII (niveles A-35 a A-24) de Vico se pueden datar grosso modo en el período orientalizante, probablemente en un momento avanzado del mismo, desde fines del siglo VII hasta la segunda mitad del siglo VI a.C. Son porcentualmente abundantes aún los recipientes fabricados a mano, como las pequeñas ollitas con digitaciones en el hombro o con decoración incisa y las bases planas muy gruesas (figs. 6 y 7); entre los recipientes hechos a torno distinguimos cerámicas grises (fig. 6: 1 y 10; fig. 7: 5), pintadas (cuencos, urnas, pithoi con o sin decoración figurativa) y comunes. En definitiva, una composición similar a la registrada en las fases III y IV de Montemolín (Bandera y otros 1993: figs. 9 y 10), en los niveles 22 y 21 de Cerro Macareno, de la segunda mitad del siglo VII y fines del siglo VII a.C. respectivamente (Pellicer y otros 1983: figs. 60 a 64), y en el nivel II (b, c y d) de Tejada la Vieja, donde se han documentado platos de cerámica gris idénticos a los de Vico, datados entre la segunda mitad del siglo VII y mediados del VI a.C. (Fernández Jurado 1987: láms. IV, 3 y XX, 14; en general láms. XXIX a XXXVI). Los estratos VII y VI de Carmona, de la segunda mitad del siglo VII hasta mediados del VI a.C., también guardan ciertos paralelismos (Pellicer y Amores 1985: figs. 22 a 26), así como el estrato IV del corte AI del Cerro de la Cabeza, fechado en el período orientalizante final o transición, a mediados del siglo VI a.C. (Domínguez y otros 1988: láms. XXXVII a XXXIX).

La secuencia desde el estrato IX hasta los últimos niveles superficiales se puede incluir dentro del período denominado convencionalmente como "turdetano". Las transformaciones técnicas, morfológicas y decorativas de la vajilla cerámica con respecto al periodo anterior, graduales y siempre a partir de los prototipos "orientalizantes", son, no obstante, evidentes: reducción de las producciones a mano hasta su desaparición o presencia residual, al igual que las cerámicas grises a torno, y desaparición de las decoraciones pintadas figurativas y de los engobes rojos.

La tecnología de la producción alfarera "turdetana" mejora sensiblemente con la preparación de pastas más depuradas y compactas, con el uso de tornos más perfeccionados y con un mayor control de la cocción. La morfología de los vasos sufre una transformación gradual hasta la creación de formas y decoraciones propias de la vajilla "turdetana", paralela -aunque con diferencias- a la génesis del repertorio cerámico púnico-gaditano (Ruiz Mata 1987; Ruiz Mata y Pérez 1995), pues ambos parten de los mismos prototipos orientalizantes. Las decoraciones tienden a la simplificación, mostrando preferencias por las bandas rojas y filetes negros, filetes de color rojo en el interior o exterior del borde de platos, cuencos y urnas, y superficies de color rojo con tonalidades que van del rojo violáceo, a veces espatulado, al rojizo diluido. 

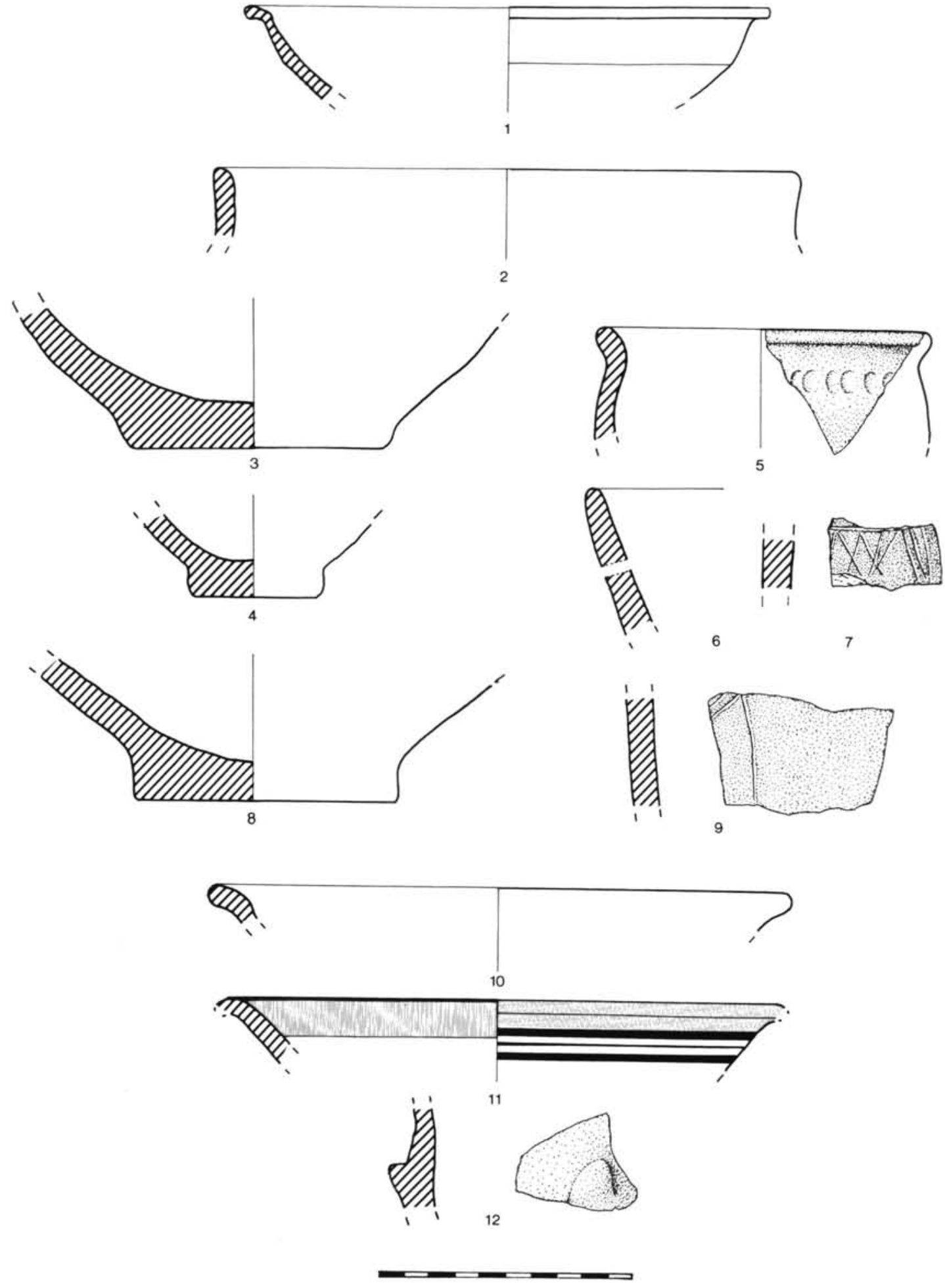

Fig. 6. Registro cerámico del estrato II (niveles A-34 a A-3 1). 

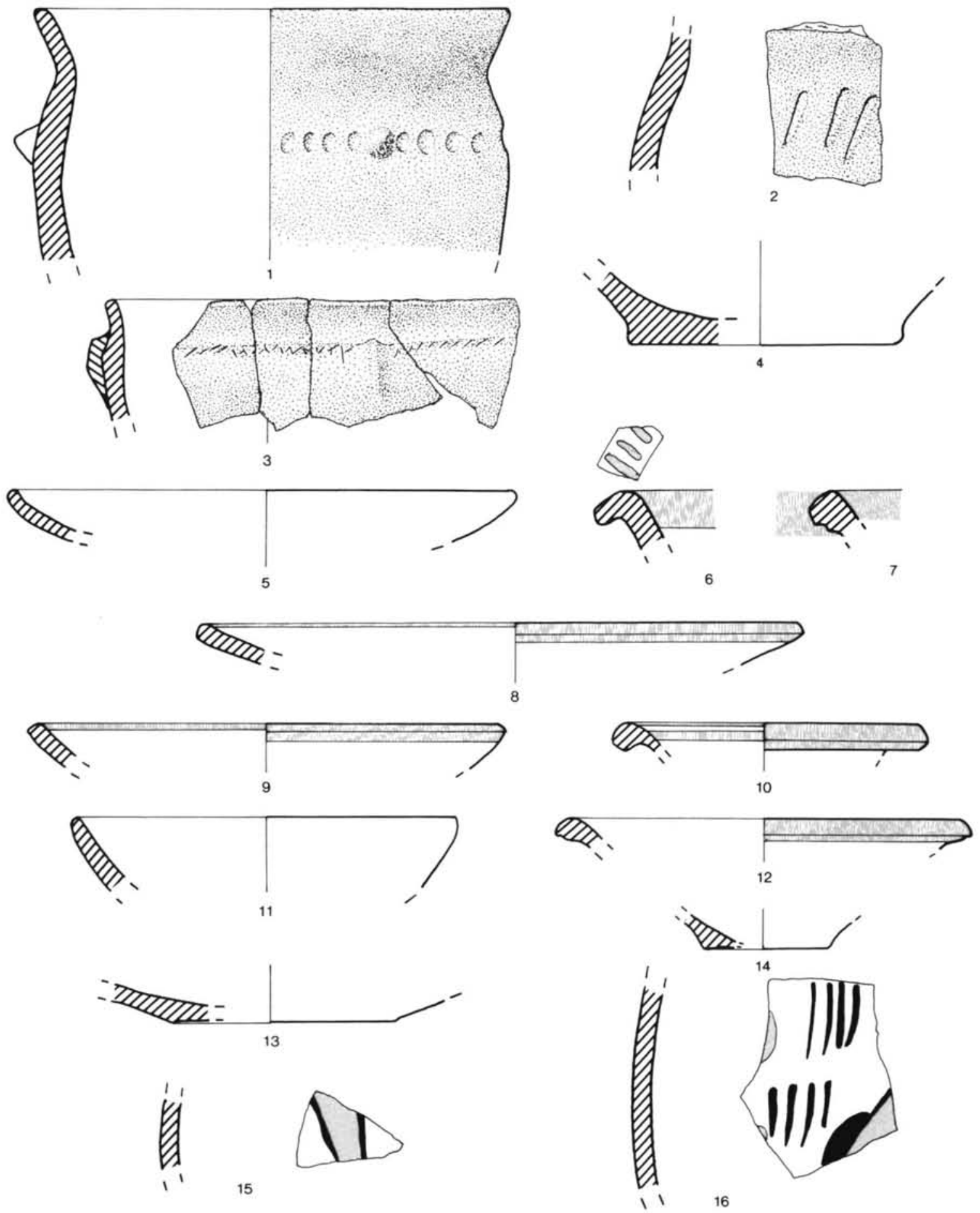

Fig. 7. Registro cerámico del estrato VIII (niveles A-25 y A-24). 
Una de las formas más características del período turdetano en Vico es el recipiente grande y profundo, también denominado lebrillo o fuente, evolucionado probablemente del pithos orientalizante. Los más antiguos, de fines del siglo VI y principios del V a.C. (figs. 8 y 9), portan aún asas trigeminadas y geminadas y decoración de bandas rojas y líneas negras; en su evolución este tipo de asas desaparece y en el siglo III a.C. apenas se decoran. Otros prototipos de origen oriental como las urnas tipo "Cruz del Negro" y los vasos a chardon se transforman dando lugar a urnas globulares (fig. 10:1 y 2) y bitroncocónicas respectivamente, generalmente pintadas (fig. 10:3 a 8); las tendencias características a lo largo del periodo serán el acortamiento de los cuellos y el exvasamiento de los bordes.

Los platos fenicios de engobe rojo dan lugar al plato "turdetano", de paredes curvas y borde recto, generalmente decorado con pintura roja en ambas caras, y otros dos grupos formales, los cuencos (fig. 12: 4 y 5) y las ollas de cocina (fig. 12:13), por lo elemental de su morfología y su funcionalidad, apenas experimentan cambios.

Un tipo de envase muy característico de este período es el ánfora turdetana (tipos Pellicer B y C; fig. 11:6 a 10), surgido morfológicamente a partir del contenedor fenicio "de saco" [T-10.1.2.1. de J. Ramón (1995: 281)], fabricado en las colonias fenicias del Extremo Occidente, e imitado en alfares indígenas ${ }^{4}$. La génesis y el desarrollo de los tipos turdetanos (Pellicer 1978: fig. 13) es paralela en su cronología a la de los tipos púnico-gaditanos (Mañá-Pascual A-4) ${ }^{5}$, pero divergente en el desarrollo morfológico, lo que evidencia claramente la distinción entre ambas tradiciones alfareras, a pesar de la génesis común y de la evolución paralela.

Volviendo a la estratigrafía comparada, el estrato X (niveles A-23a y A-22) de Vico se puede fechar grosso modo a fines del siglo VI o principios del V a.C.; la cronología relativa se define por el hallazgo de un asa de kylix griego (fig. 12: 6) y por los evidentes paralelos que presenta con los niveles 18 a 16 de Cerro Macareno (fines del siglo VI a segundo cuarto del siglo V a.C.), concretamente en lo que respecta a las ánforas, las urnas de cuerpo globular y los vasos a chardon evolucionados -uide supra-(Pellicer y otros 1983: figs. 52, 53, 55, y 56). Es curioso el hallazgo en Vico de un graffiti (fig. 11:9) idéntico al registrado sobre ánforas de Carmona, Cerro Macareno y de otros puntos del Mediterráneo Occidental con cronologías que oscilan entre el siglo V a.C. y el I d.C., y cuyo significado se desconoce (Belén y otros 1997: 84; fig. 9, 1).

Los estratos XI a XVI (niveles A-21 a A-17s) de Vico se pueden datar a lo largo del siglo V a.C. por la semejanza que presenta con el registro cerámico de los estratos I y II del corte BI del Cerro de la Cabeza, fechados en torno al siglo V y en los inicios del IV a.C. (Domínguez y otros 1988: láms. I a VII); y de los niveles 15 a 13 de Cerro Macareno (Pellicer y otros 1983: figs. 47 a 43). Las concomitancias entre Vico y Cerro Macareno vuelven a ser del todo evidentes en los contextos arqueológicos correspondientes al siglo IV a.C. Se pueden establecer claros paralelos en la composición del estrato XVII (niveles A-16 a A-14) de Vico y de los niveles 14 a 12 de Cerro Macareno, de fines del siglo V y primera mitad del IV a.C.

Asimismo el nivel 12 de Cerro Macareno, de mediados del siglo IV a.C., puede ser orientativo para datar relativamente los contextos arqueológicos registrados en los estratos XX (A-13 a A-11s, figs. 13 y 14) y XXII (A-12n y A-11n; fig. 15: 1 a 6). Es ahora cuando se registran en Vico tipos anfóricos de fabricación púnico-gaditana pertenecientes a los tipos T-11.2.1.3., T-11.2.1.5 y T-11.2.1.6., cuya producción finaliza a fines del siglo $\mathrm{V}$ o principios de IV a.C., y al tipo T-12.2.1.1. (fig. 15: 12 a 14), que se configura como tal en la mitad o segundo cuarto del siglo IV a.C. (Ramón 1995: 235-238).

4. "La fabricación de las T-10.1.1.1 que, ..., no son exactamente una estricta reproducción de ningún tipo oriental, sino una versión personalizada y particular a partir de distintas concepciones levantinas, se inició antes de la mitad del siglo VIII a.C. en más de uno de los asentamientos existentes en la costa de Andalucía...". A partir de este tipo, se da una multiplicidad de variantes agrupadas por J. Ramón (1995: 279-280) en el tipo T-10.1.2.1., que también fueron fabricadas en los asentamientos del área del Estrecho de Gibraltar y en lugares "excéntricos" como Pinos Puente (Granada) o Peña Negra (Alicante).

5. Agrupado por J. Ramón (1995: 233) en G-1 1.2.0.0. 

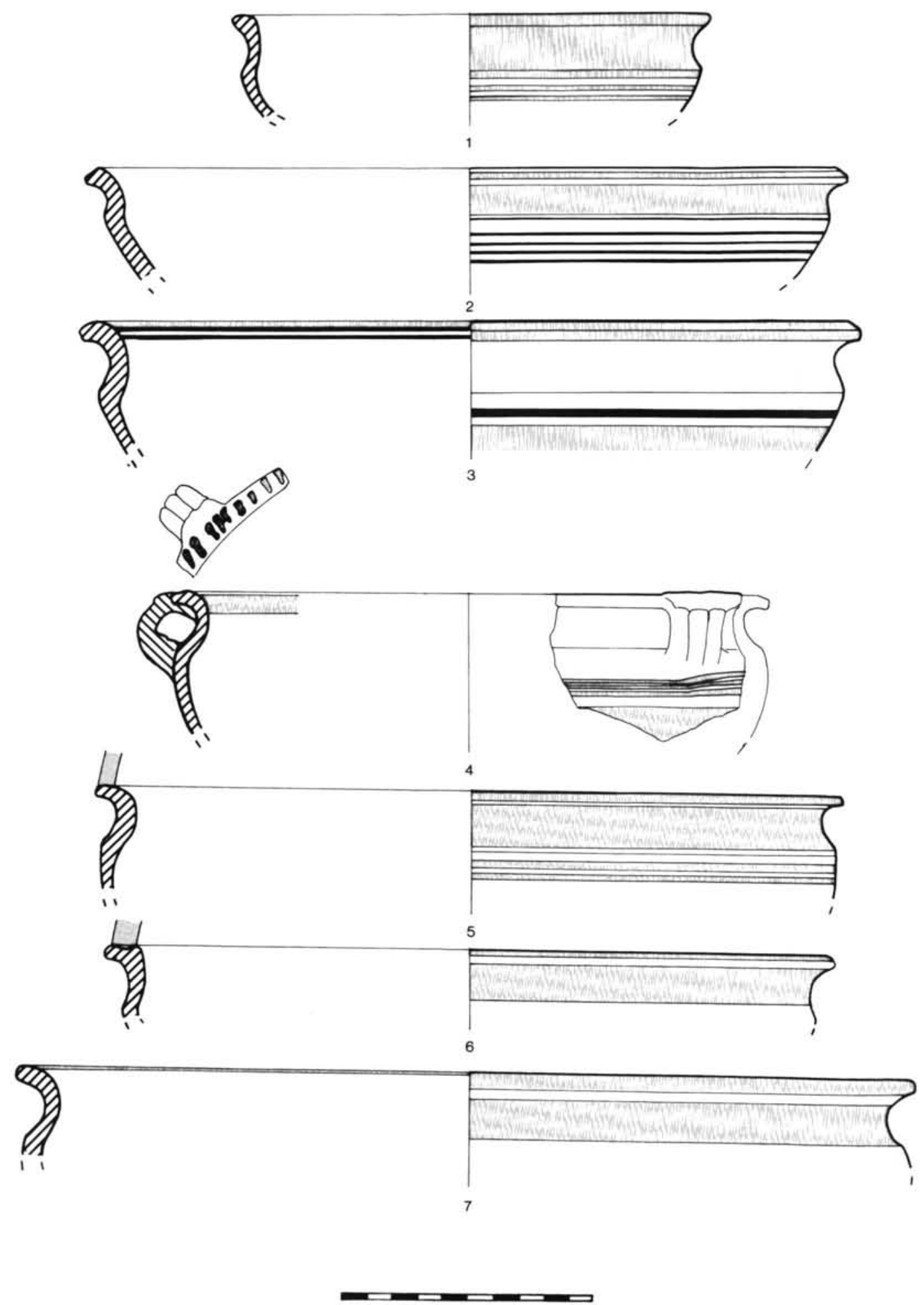

Fig. 8. Registro cerámico de los estratos X y XI (niveles A-23 y A-22). 


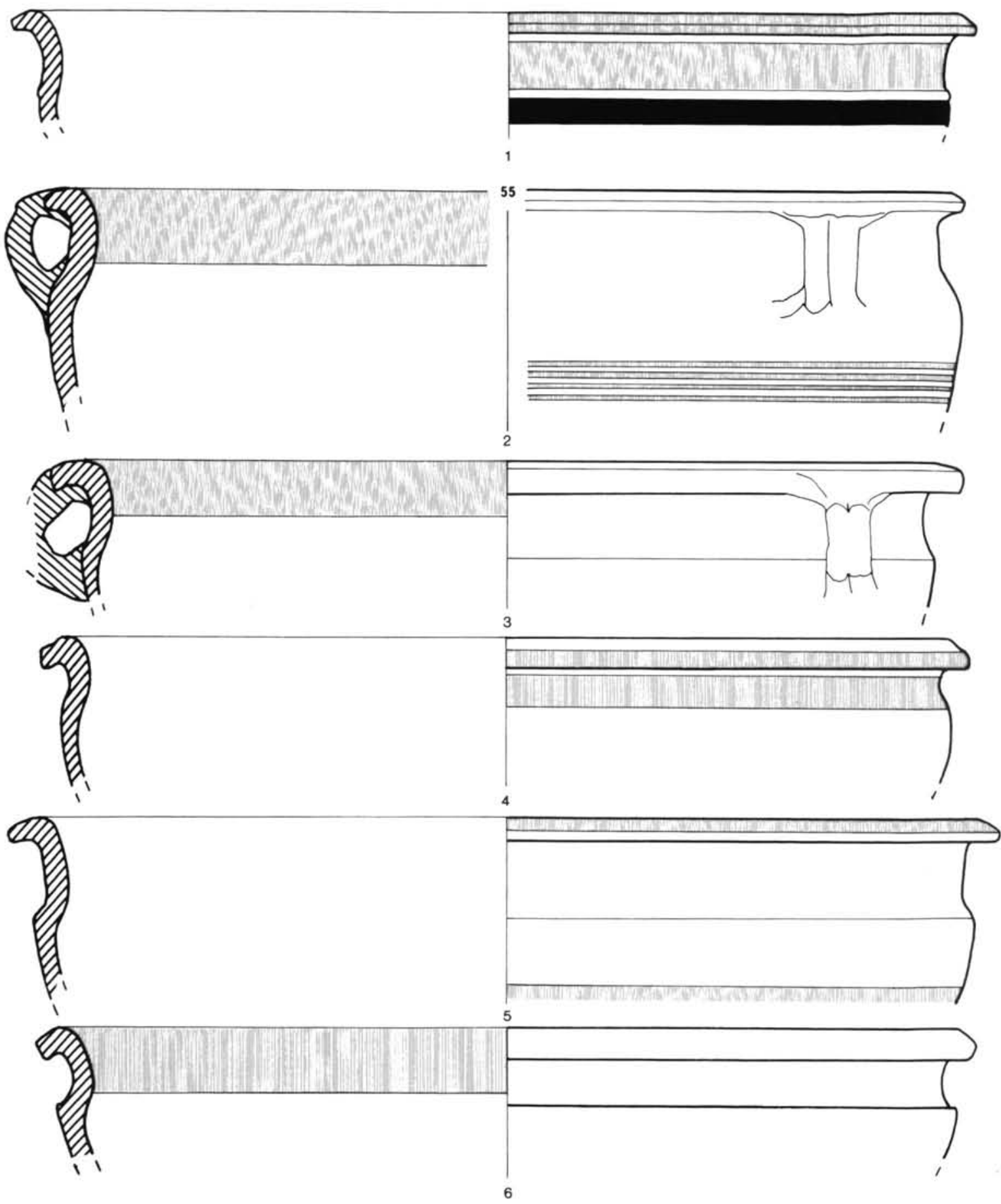

Fig. 9. Registro cerámico de los estratos X y XI (niveles A-23 y A-22). 


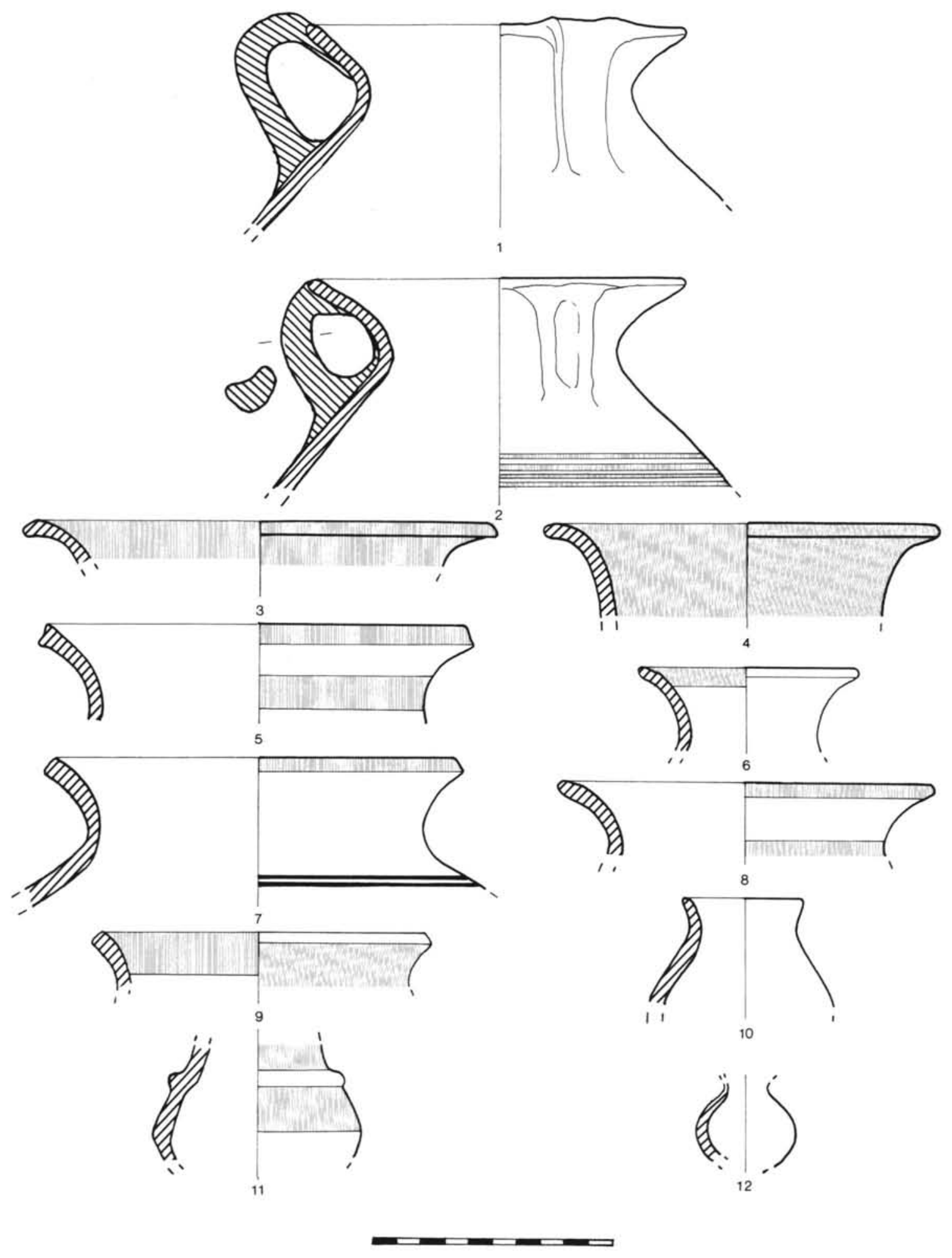

Fig. 10. Registro cerámico de los estratos X y XI (niveles A-23 y A-22). 

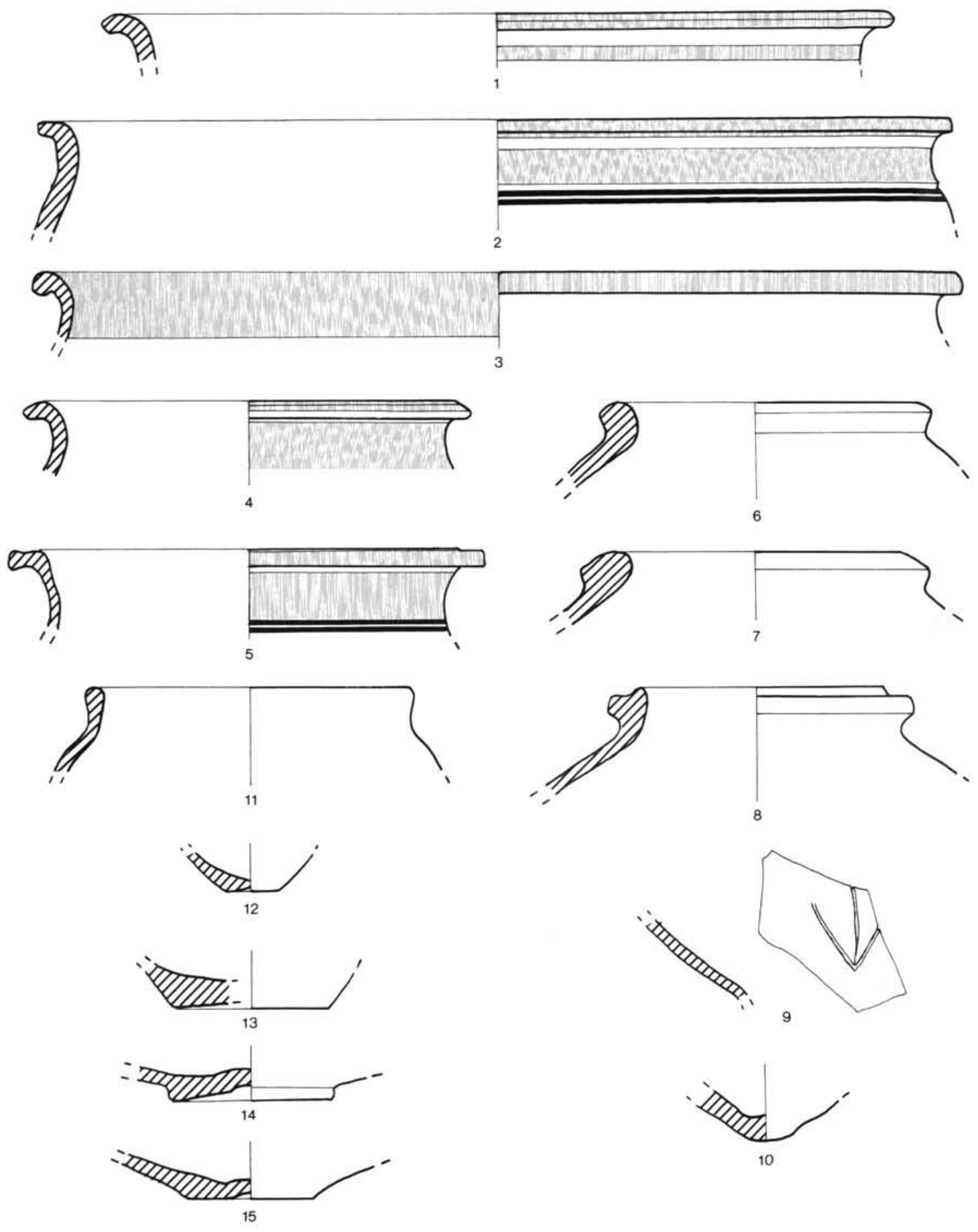

Fig. 11. Registro cerámico de los estratos X y XI (niveles A-23 y A-22). 

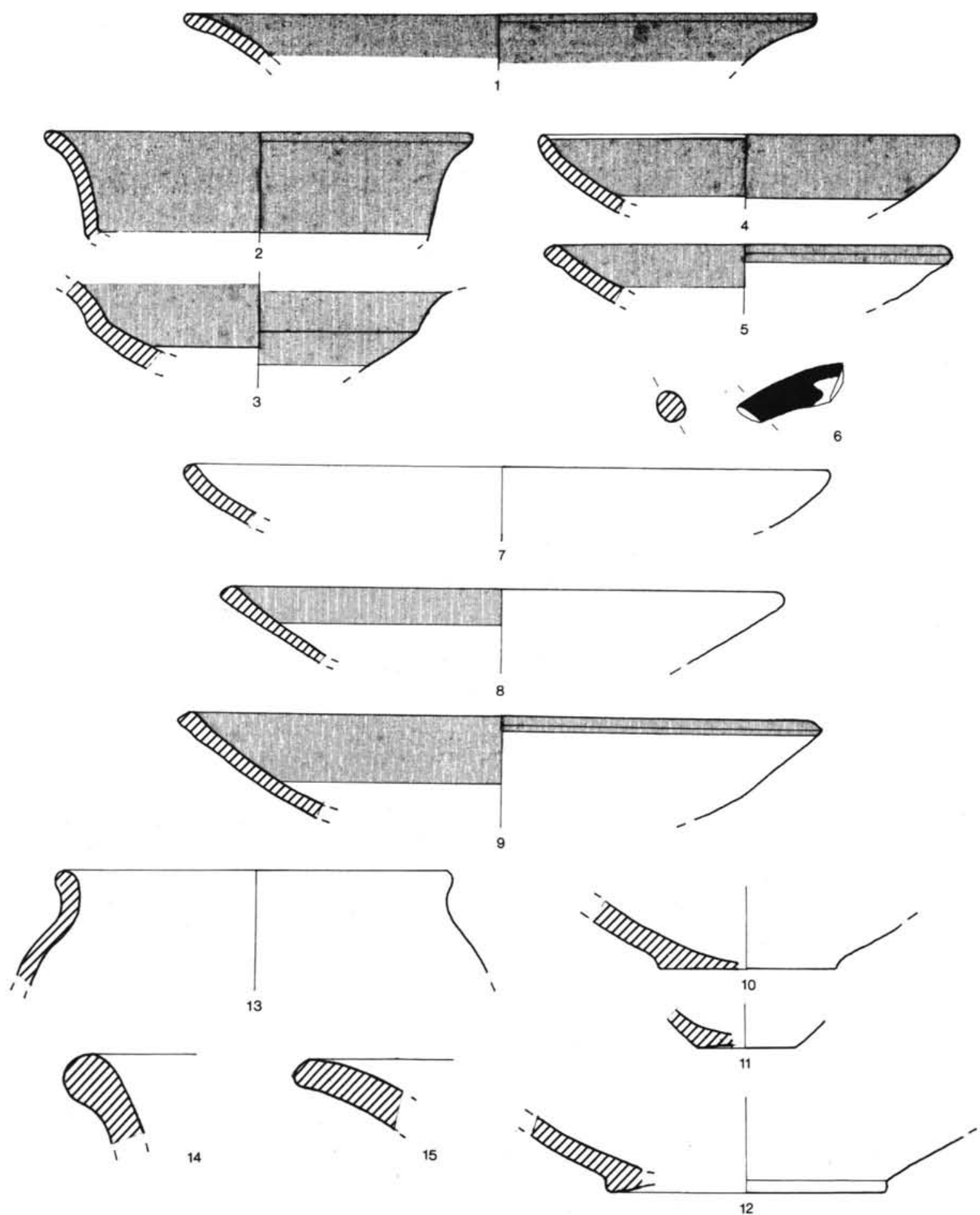

15
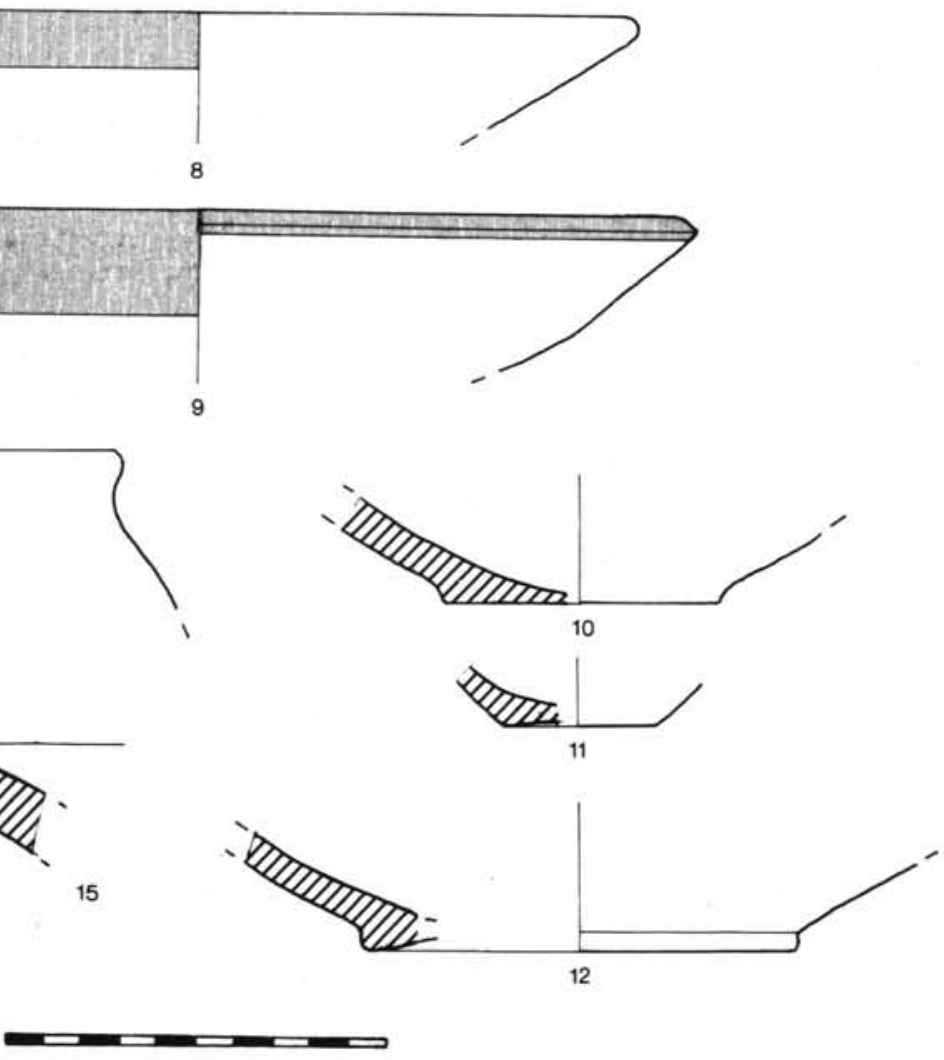

Fig. 12. Registro cerámico de los estratos X y XI (niveles A-23 y A-22). 

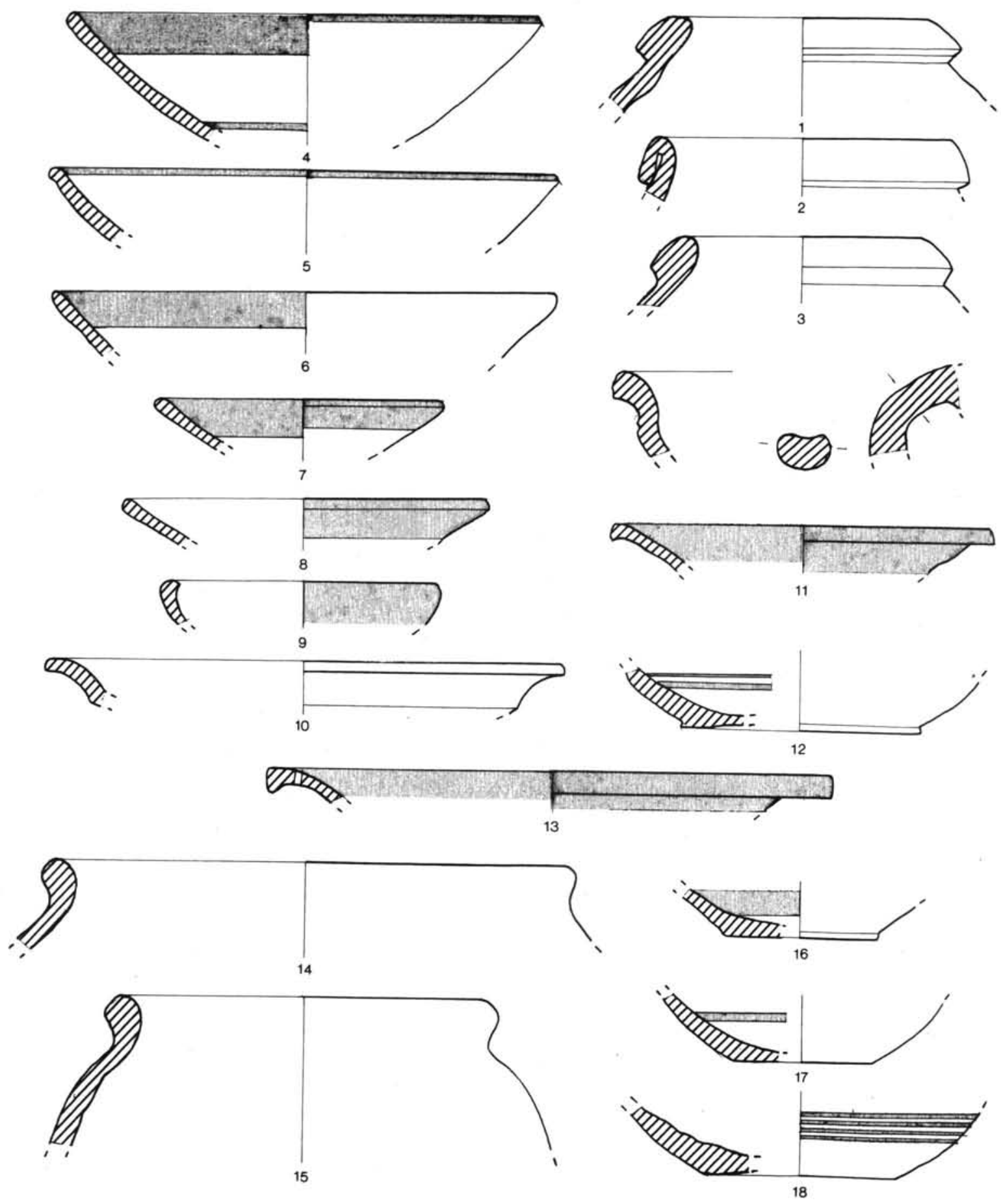

Fig. 13. Registro cerámico del estrato XX (niveles A-13, A-12s y A-11 s).

ISSN: $1133-4525$ ISSN-e: 2255-3924 

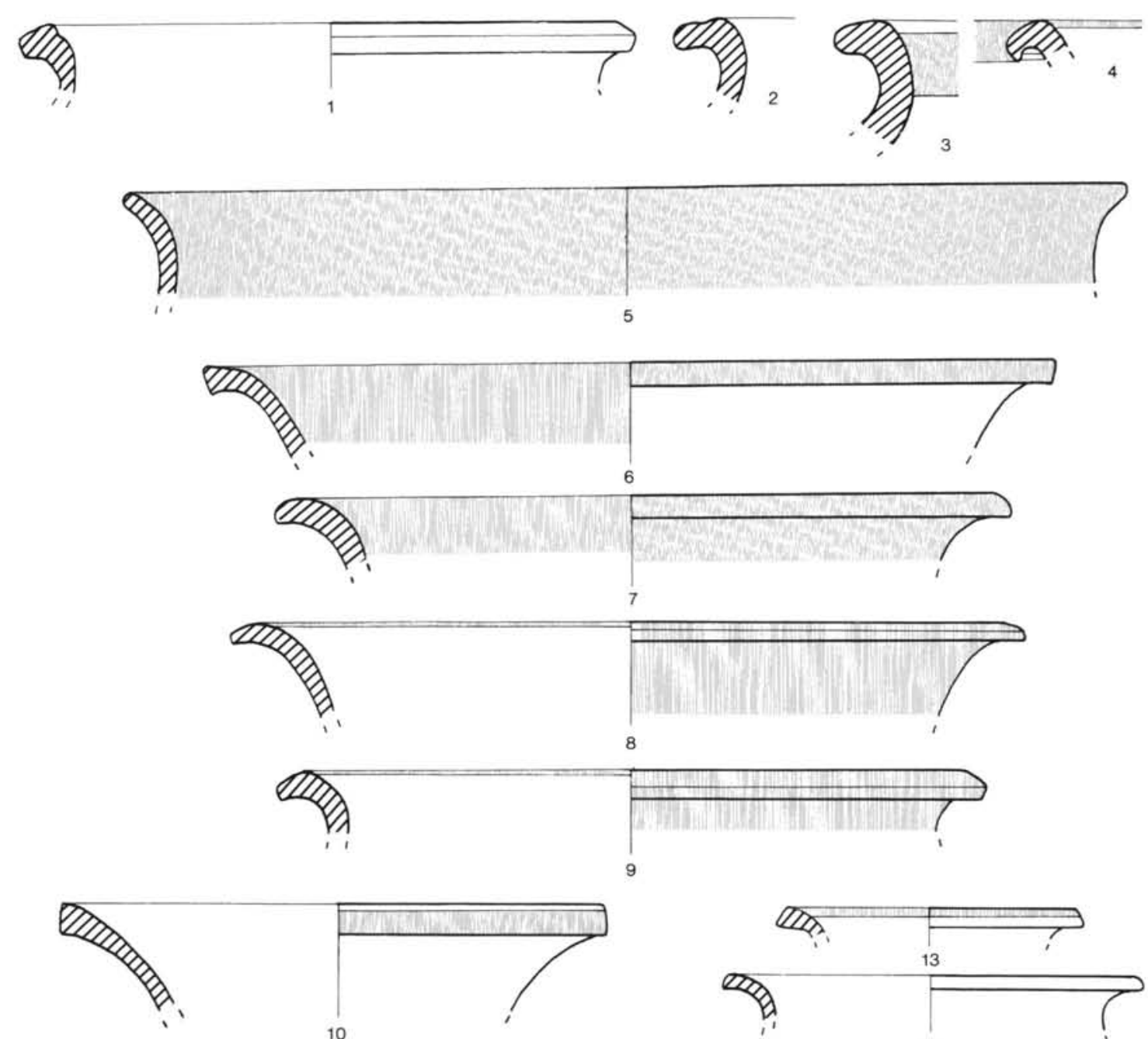

10
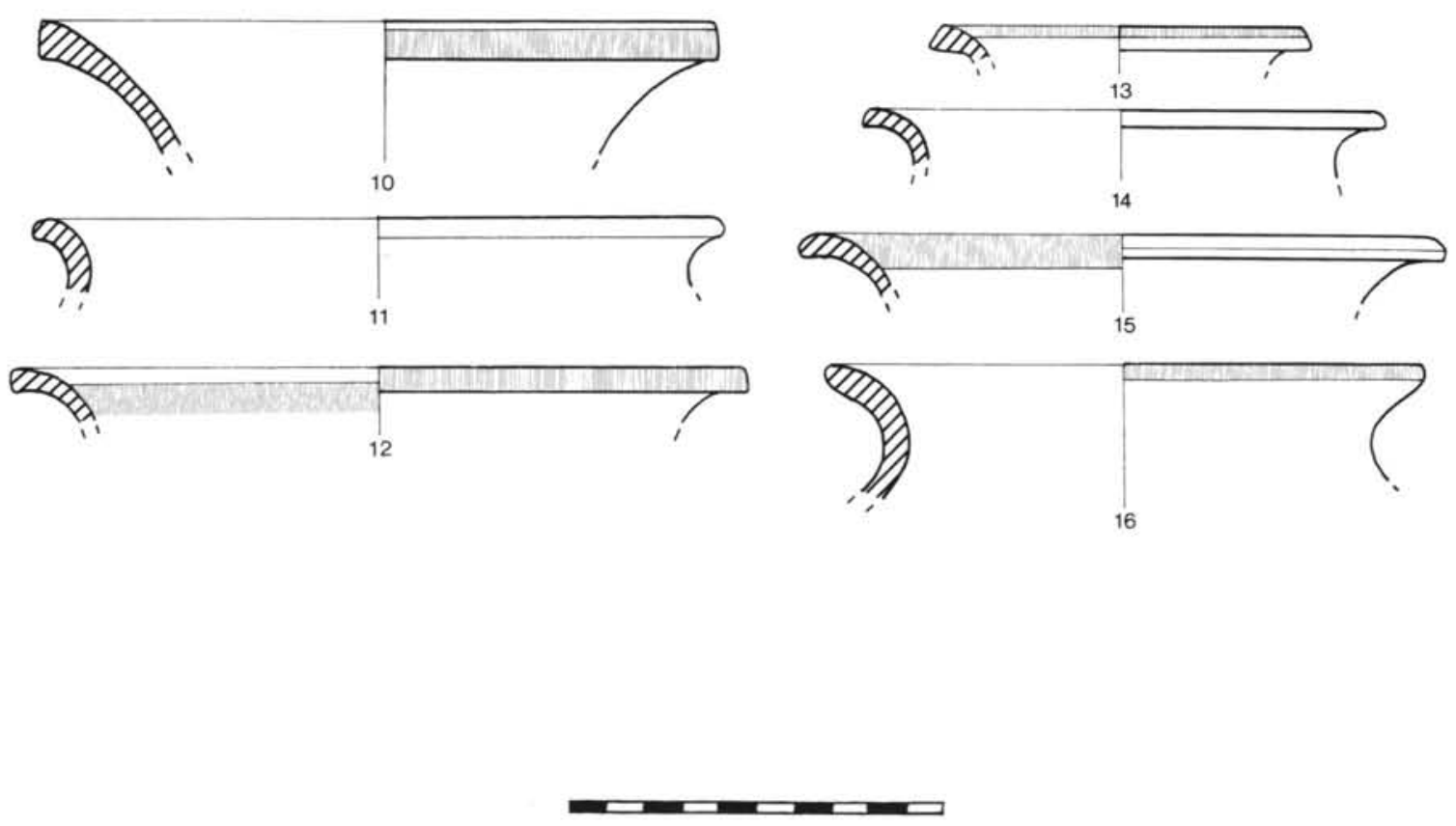

Fig. 14. Registro cerámico del estrato $X X$ (niveles A-13, A-12s y A-1 l s). 

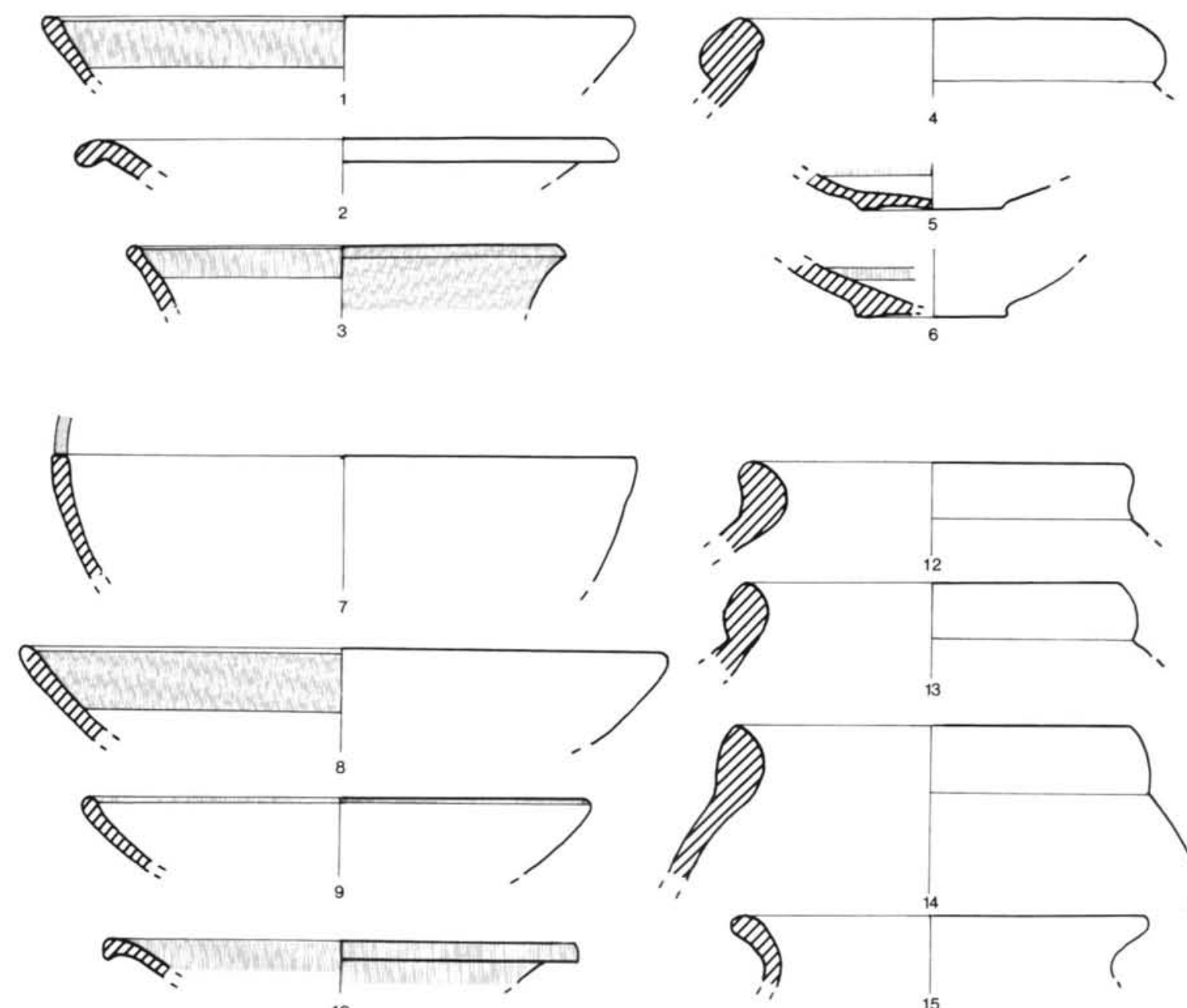

10
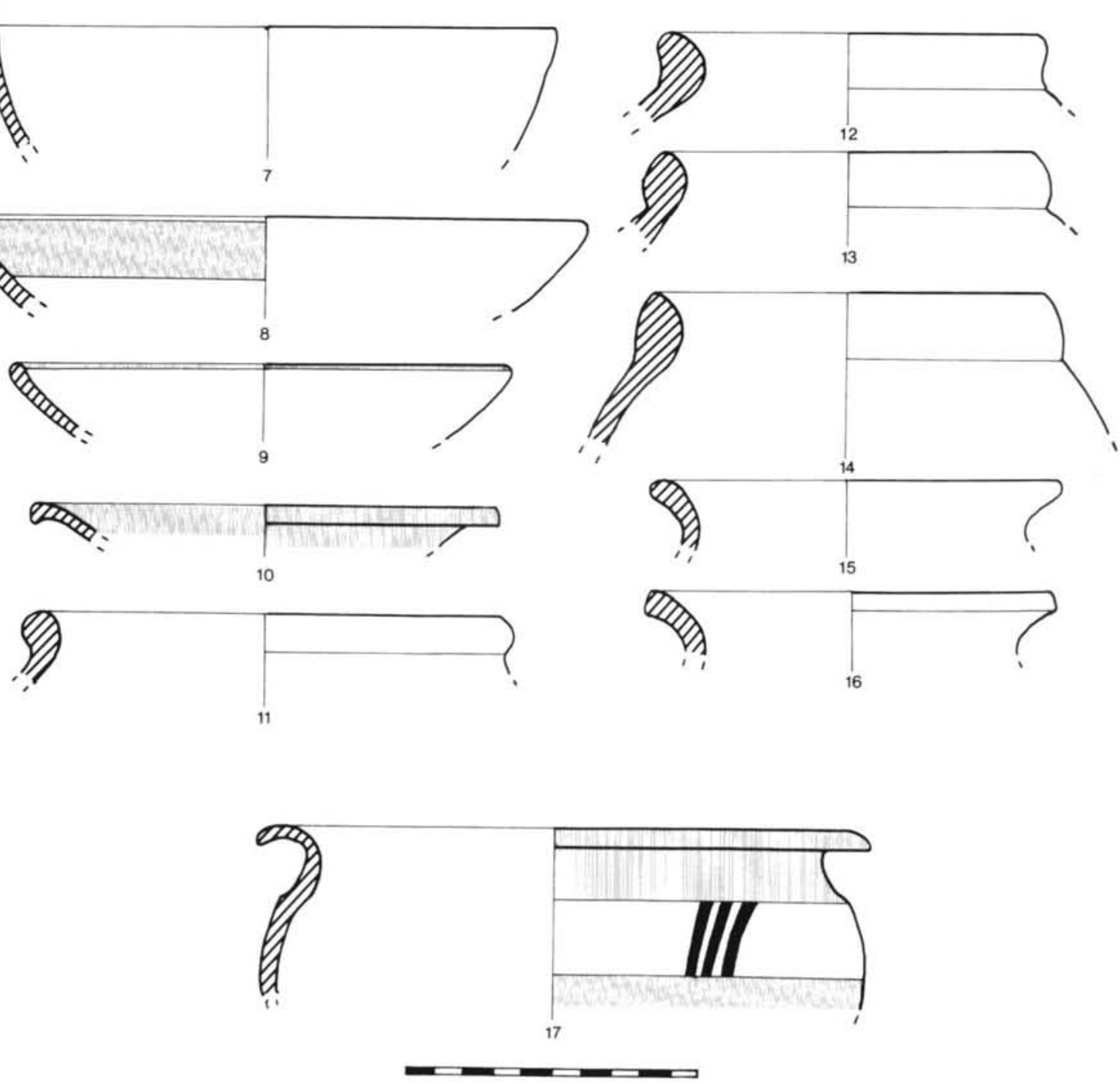

Fig. 15: 1 a 6: registro cerámico del estrato XXII (niveles A-12n y A-11 n); 7 a 17: registro cerámico del estrato XXI (A-11 zanja de muro). 
Los estratos restantes, niveles 10 a 5, de Vico deben ser datados entre la segunda mitad del siglo IV y el último tercio del siglo III a.C. De hecho los niveles 6 y 5 , un estrato con restos de incendio y de derrumbe, se corresponden con la última fase de habitación de Montemolín, contextualizable en la segunda Guerra Púnica (García y otros 1989: 242; Bandera y otros 1993: 33). El registro cerámico característico de este momento está representado por vasos de perfil quebrado y tulipiformes decorados con filetes rojos, urnas de cuello corto, vasos caliciformes, cuencos-lucerna, cuencos con bordes biselados muy característicos, platos de diámetro reducido, ollitas de cocina, lebrillos y ánforas turdetanas y púnico-gaditanas de los tipos T-8.2.1.1. y T-12.1.1.1. (figs. 16 a 18$)^{6}$.

Los cinco últimos niveles de la secuencia (A-4 a A-sup.) están alterados aunque se puede reconocer en ellos la continuidad del poblado hasta época altoimperial por la presencia de materiales republicanos y altoimperiales.

\section{CONCLUSIONES}

La secuencia estratigráfica de Vico, completada con la de Montemolín, documenta el origen y desarrollo de un asentamiento tartesio-turdetano cuya vida se prolonga sin interrupción a lo largo de todo el $\mathrm{I}^{\mathrm{er}}$ milenio a.C., adaptándose tras la segunda Guerra Púnica a las nuevas estructuras administrativas y sociales que la romanización impuso, las cuales, y quizás como consecuencia de los avatares previos durante la segunda Guerra Púnica, probablemente redujeron su papel de asentamiento de primer orden a un puesto muy secundario en la articulación y administración del territorio, en favor de otros centros como Carmo, Urso o Astigi.

Desconocemos si con anterioridad al Bronce Final hubo habitación en Vico, porque como ya se ha advertido, no se pudo registrar la secuencia completa. Sí sabemos que durante este período, en un momento que se puede datar grosso modo en el siglo IX a.C., Montemolín era ya un asentamiento estable (Bandera y otros 1993). Responde, como otros asentamientos tartesios ${ }^{7}$, a un comportamiento poblacional que generó sincrónicamente la fijación de la población en lugares de interés estratégico-defensivo y económico, inaugurando un patrón de asentamiento muy estable en el tiempo, característico de la campiña y del valle del Guadalquivir, que va a perdurar en época romana y en muchos casos hasta la actualidad (Ferrer y otros 2001).

Podemos interpretar este fenómeno como una consecuencia del proceso de transformación de las comunidades tartesias hacia una mayor complejidad social, pues la misma apropiación y ocupación de lugares con determinadas características (visibilidad, control, etc.) indican la voluntad -y la posibilidadde una comunidad determinada de establecer su hegemonía sobre territorios y sobre otras comunidades. La estela hallada en Montemolín (Chaves y Bandera 1982), ya sea interpretada como epitafio, estela funeraria o como indicador territorial, avala la idea de una sociedad no igualitaria e incipientemente jerarquizada, cuya cúspide estaría ocupada por una elite guerrera (Ferrer 1999b: 70).

6. El primero de los tipos gaditanos se data, según J. Ramón (1995: 226), entre la primera mitad del siglo IV y fines del siglo III a.C., aunque su fabricación en los talleres de Torre Alta (San Fernando, Cádiz) es una garantía de la continuidad de su uso durante el siglo II a.C. (de Frutos y Muñoz 1996: 140). El tipo T-12.1.1.1. y sus derivaciones tiene una cronología similar, aunque perdura durante todo el siglo Il y algunas decenas del I a.C. (Ramón 1995: 238).

7. La nómina de asentamientos tartésicos del Bronce Final precolonial era exigua hasta hace poco (Belén y Escena 1991); no obstante, las prospecciones y excavaciones arqueológicas en la campiña de Córdoba (Murillo 1994) y Sevilla (Ferrer, Oria y García 2001), y excavaciones recientes como las de Osuna (Ferrer, Ruiz y García e.p.) han ampliado sustancialmente la nómina de yacimientos datables en este período, aunque aún no se ha solucionado el problema de la discontinuidad poblacional. 

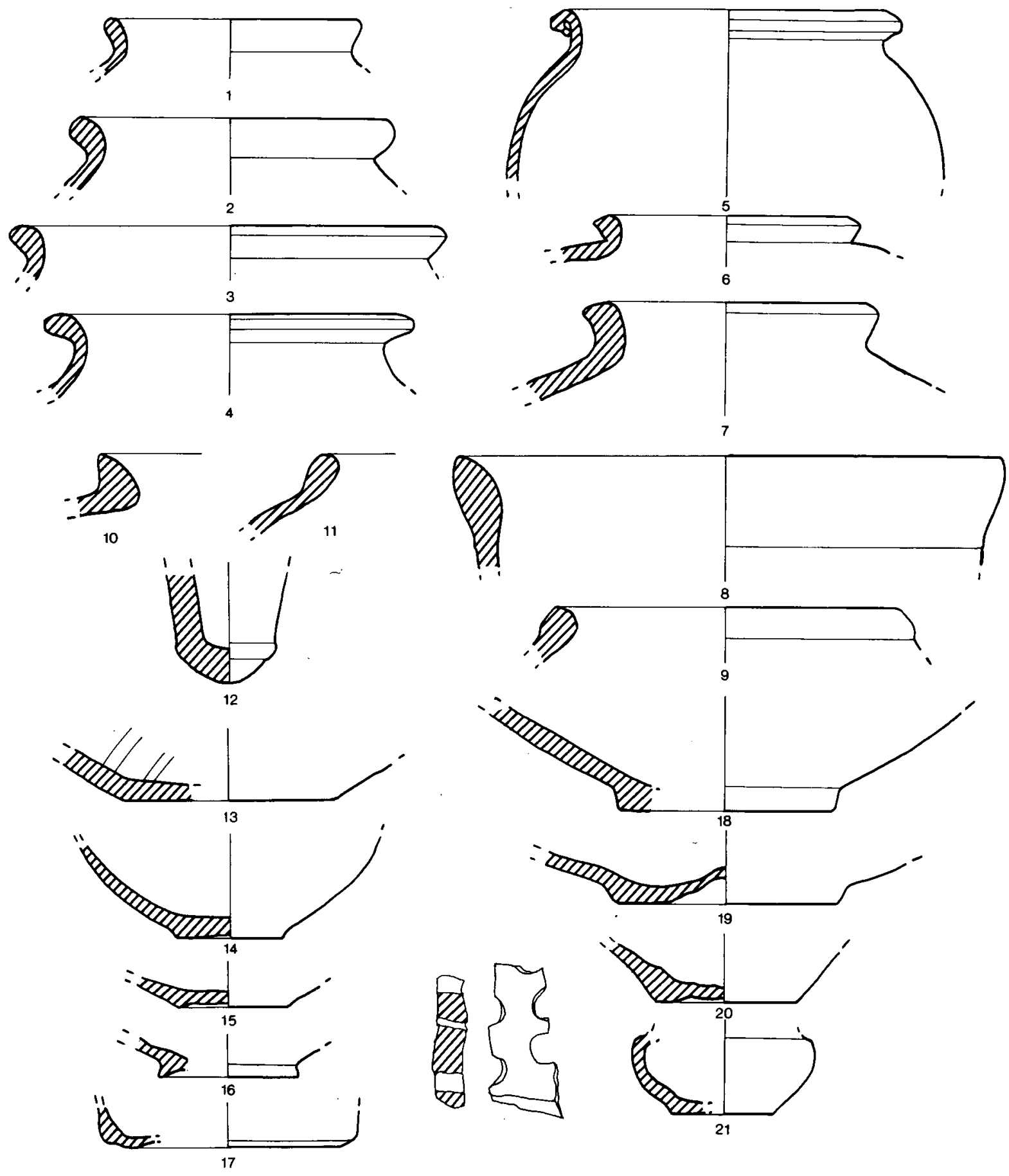

Fig. 16. Registro cerámico del nivel A-6 (estrato XXVIII). 

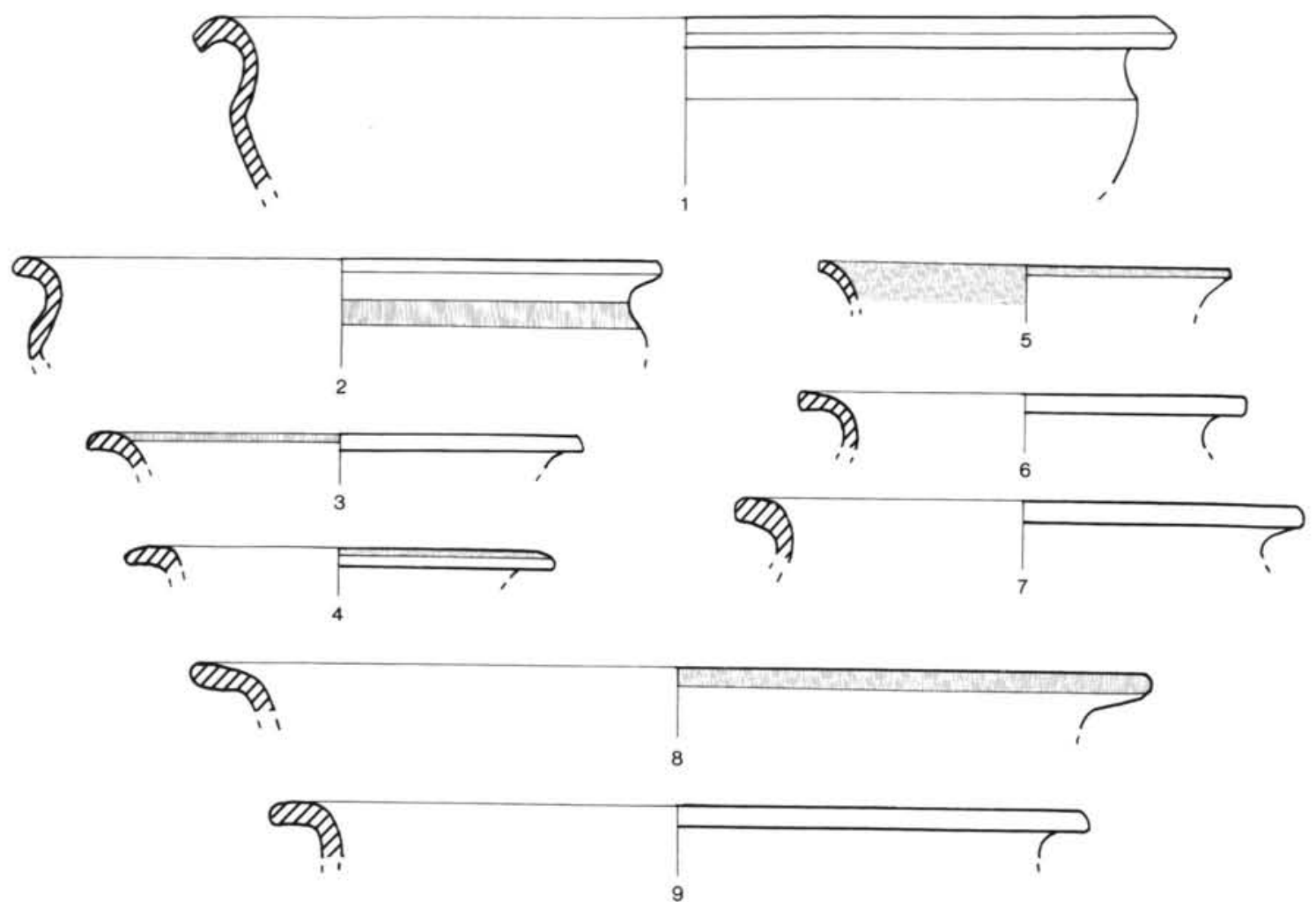

Q
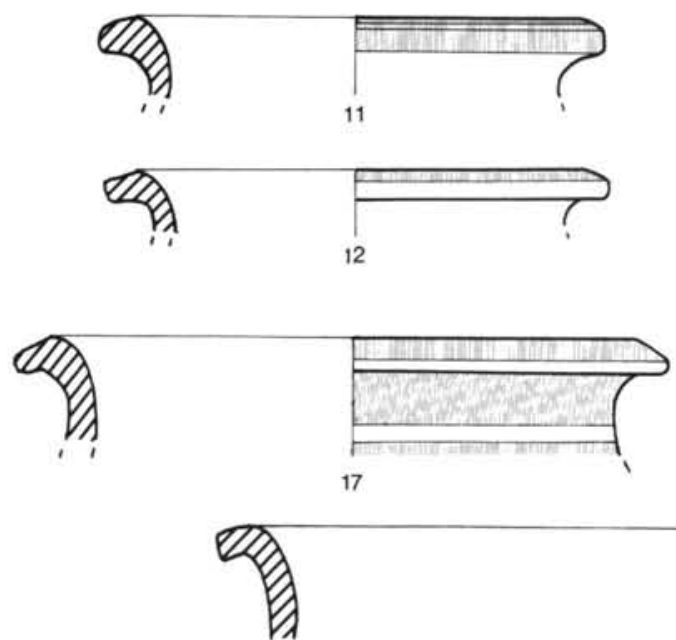

17
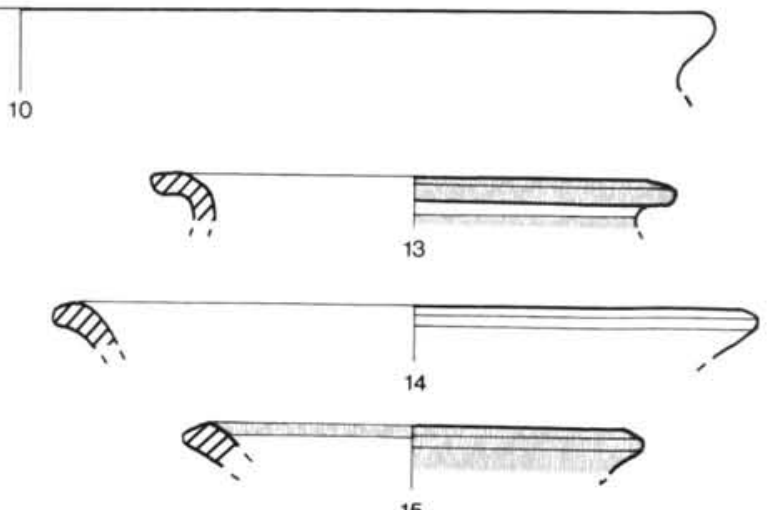

15

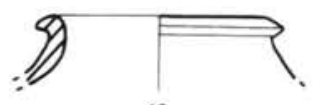

16

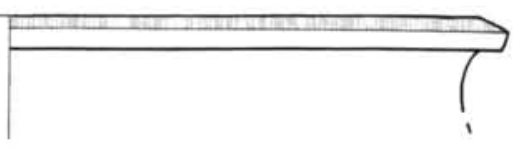

18

Fig. 17. Registro cerámico del nivel A-6 (estrato XXVIII). 

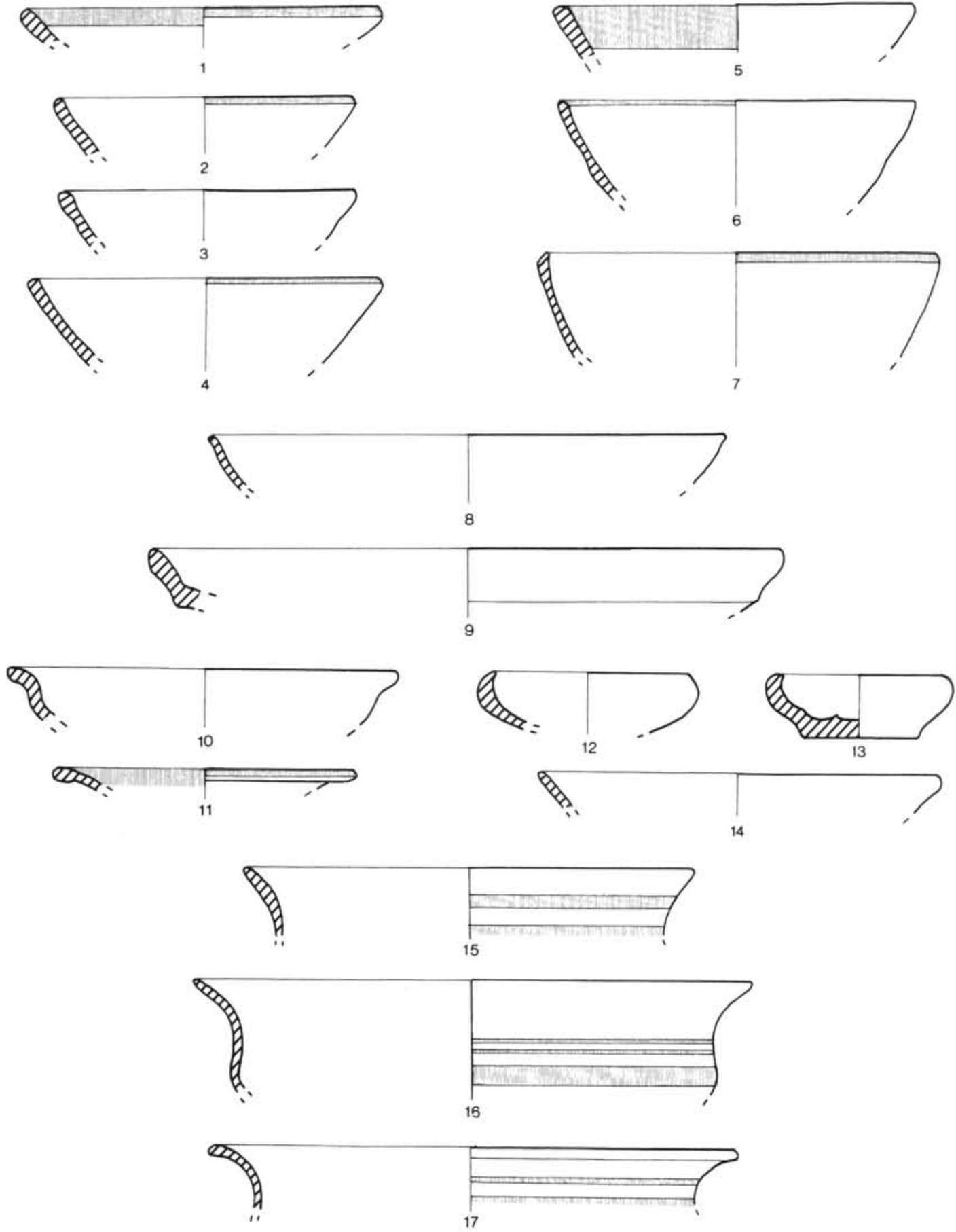

Fig. 18. Registro cerámico del nivel A-6 (estrato XXVIII).

ISSN: 1133-4525 ISSN-e: 2255-3924

SPAL 11 (2002)
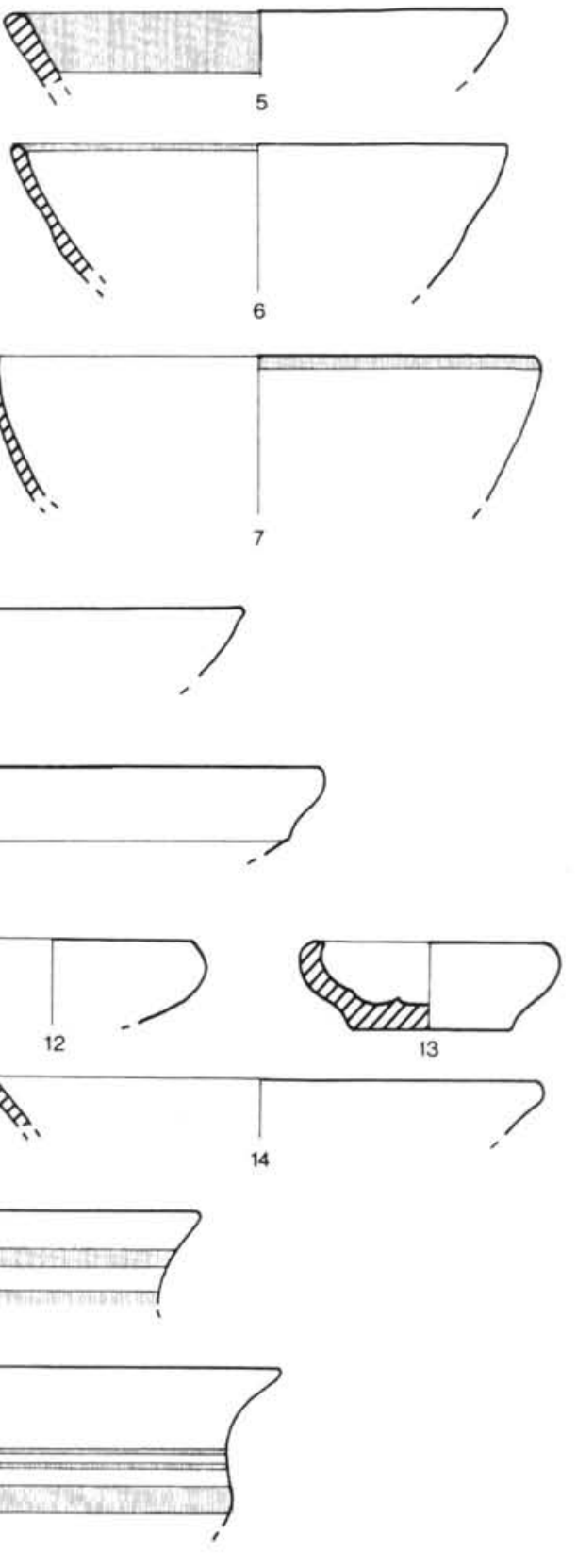
Que la comunidad tartesia de Montemolín-Vico era socialmente compleja parecen demostrarlo los prematuros contactos del poblado con las comunidades fenicias establecidas en las costas del sur de Iberia. Como se ha señalado en relación a los modelos complejos de interacción de la II Edad del Hierro en el Mediterráneo occidental, para que dos comunidades (para el caso que nos ocupa, la tartesia y la fenicia) mantengan relaciones de intercambio es preciso que la organización socioeconómica de ambas esté lo suficientemente desarrollada como para permitir la producción excedentaria y la diversificación de los papeles económicos que los intercambios implican (Gracia 1995: 179).

La colonización fenicia aceleró este proceso y debió afectar profundamente al asentamiento. Los datos arqueológicos de Montemolín indican que a fines del siglo VIII a.C. esta comunidad empezó a incorporar no sólo productos de lujo (alimentos, joyas) y nuevas tecnologías (torno, técnicas y materiales de construcción) procedentes de las comunidades fenicias asentadas en Iberia, sino también otros elementos económicos e ideológicos que transformaron profundamente la vida el poblado durante el período orientalizante. A fines del siglo VII y durante la primera mitad del VI a.C., la actividad documentada en los edificios de Montemolín arrojan pocas dudas sobre la orientalización de esta comunidad, fenómeno que sin duda se debió a la instalación en el poblado de alguna comunidad o de individuos de procedencia u origen oriental. La acrópolis del asentamiento fue sede de un complejo sacrificial donde se inmolaban especies domésticas según unas reglas determinadas de claro origen próximo-oriental (Bandera y otros 1995; Bandera y Ferrer 1998; Bandera y otros 1999; Chaves y otros 2000).

Montemolín constituyó el centro cultual y Vico el poblado asociado a éste, en el contexto espacial de una región densamente poblada que había experimentado una intensa ocupación del espacio rural mediante la creación de varias decenas de asentamientos de pequeño tamaño o "granjas" dedicadas a la explotación agrícola ${ }^{8}$. Sin embargo, la vida de éstos será efímera y no trascenderá el período orientalizante, al igual que los edificios de la acrópolis, que no sobrevivirán a la segunda mitad del siglo VI a.C. La razón de esta profunda transformación en el asentamiento nos es desconocida, pero la sincronía con fenómenos similares en todo el territorio tartesio (Escacena 1993) hace pensar en causas estructurales y no locales.

La vida del poblado continuó en Vico y la acrópolis se deshabitó hasta el siglo III a.C. La reocupación de Montemolín (García y otros 1989; Bandera y otros 1993) pudo estar en relación con el levantamiento de un campamento cartaginés en el cerro (Chaves 1991; Ferrer 1999a). Pasada la contienda y vuelto a despoblar Montemolín, Vico será el asentamiento permanente hasta su desaparición en un momento indeterminado posterior a época altoimperial romana.

Un aspecto interesante del yacimiento en relación a su función en época romana es su topónimó, que parece proceder del término latino uicus (Ordóñez 1996: 51), cuyas derivaciones son ciertamente habituales en Galia (Vic, Vicq, Vichy, Vy, Vieu) e Hispania-Vigo, Vico, Vich-(Curchin 1985: 335). De ser cierto este origen, sobre el cerro de Vico debió constituirse un uicus. No obstante, el significado de este término en Hispania no es, como ha señalado Curchin (1985:335-336), unívoco, y puede tener varios significados: en el caso de dos uici de Corduba, son subdivisiones urbanas o barrios de la capital provincial, uno habitado por hispanos y otro por itálicos, probablemente con función de distritos de voto. El uicus de la Numancia prerromana también debió ser una subdivisión de la ciudad, y el resto de los uici hispanos documentados parecen ser asentamientos rurales localizados en áreas indígenas. El hecho de que pudieran tener sus propios magistrados -aunque ninguno ha sido atestiguado en Hispania - sugiere una cierta capacidad de independencia local, de manera que, aunque a veces dependieran de ciudades mayores, los uici debieron ser las unidades políticas más pequeñas con capacidad de autogobierno, y tener un papel en la administración territorial y en el control de un pequeño territorio (Cortijo 1993: 205 ss.).

8. La vocación agrícola de estos asentamientos es indiscutible por el utillaje lítico registrado en ellos: dientes de hoz con pátina de siega, molinos barquiformes, moletas, etc. (Ferrer y otros 2000; Ferrer y otros 2001). 
Dadas las relaciones del yacimiento con el territorio y su contexto arqueológico, se puede interpretar que Vico fuese "una aldea dentro del territorio de una ciuitas o de un castelllum u oppidum al que estuviese adscrito" (Ordóñez 1996: 51). El actual término de Marchena, además de Vico, tuvo otras dos aglomeraciones mayores que pueden ser identificadas como uici: Porcún y Pozo Blanquillo; en los tres casos son asentamientos importantes en época turdetana y durante la segunda Guerra Púnica, lo cual "parece indicar una pervivencia de la organización tradicional de época prerromana, que en la epigrafía de la zona se refleja con la mención de centurias de nombre indígena. Estas centurias corresponden a circunscripciones territoriales, equiparable a los pagi de la organización colonial romana, que tienen como centro de población a un uicus" (Ferrer, García y Oria 2000: 99).

La ciuitas, castellum u oppidum del que dependería Vico y los otros asentamientos identificados como uici pudo ser una de las tres comunidades cuyos territorios se repartían el actual término de Marchena: Carmo, Urso o Astigi, la primera de las cuales fue un municipio latino y las otras dos colonias romanas, cesariana y augustea respectivamente. Como el modelo de ocupación del territorio es una herencia del período turdetano, no es aventurado pensar que la mayor parte del término, y con ella Vico, correspondiera a Carmo, cuyo estatus municipal pudo suponer la pervivencia de las estructuras indígenas, entre ellas las territoriales. No obstante hay que tener presente las modificaciones en el reparto territorial que se introducen en época flavia por la creación de dos nuevos municipios, Obulcula (La Monclova, Écija) y el situado en el Cerro de la Balas, y quizás un tercero, Artigi (Cortijo de la Torre, en Marchena, según González 1996: 1992), que pudieron afectar al término marchenero tanto en cuanto a estos nuevos municipios se le debieron asignar territorios (Ferrer, García y Oria 2000: 95-96).

\section{BIBLIOGRAFÍA}

AGUAYO, P.; CARRILERO, M.; DE LA TORRE, Ma. y FLORES, C. (1986): "El yacimiento pre y protohistórico de Acinipo (Ronda, Málaga): un ejemplo de cabañas del bronce Final y su evolución", Arqueología Espacial 9: 33-58.

AMORES CARREDANO, F. (1979-80): "El poblamiento orientalizante en Los Alcores (Sevilla): hipótesis de un comportamiento", Habis 10-11: 361-375.

(1982): Carta Arqueológica de Los Alcores (Sevilla). Universidad de Sevilla.

AMORES, F. y RODRÍGUEZ TEMIÑO, I. (1984): "La implantación durante el Bronce Final y el Período Orientalizante en la región de Carmona", Arqueología Espacial 4: 98-113.

BANDERA, Ma.L. de la; CHAVES, F. y FERRER, E. (1999): "Ganado, sacrificio y manipulación de carnes. Una propuesta aplicada al período orientalizante", II Congreso de Arqueología Peninsular II: 213-219.

BANDERA, Mª.L. de la; CHAVES, F.; FERRER, E. y BERNÁLDEZ, E. (1995): "El yacimiento tartésico de Montemolín", Tartessos 25 años después (1968-1993). Congreso Conmemorativo del V Symposium Internacional de Prehistoria Peninsular: 315-332. Jerez de la Frontera.

BANDERA, Ma.L. de la y FERRER, E. (1998): "Indicios de carácter económico y ritual de tradición próximo oriental en el sur de Iberia", Actas en Internet del I Congreso Español de Antiguo Oriente Próximo. El Mediterráneo en la Antigüedad: Oriente y Occidente. Madrid. http://www. labherm.filol.csic.es

BANDERA, Mª.L. de la; CHAVES, F.; ORIA, M.; FERRER, E.; GARCÍA, E. y MANCEBO, J. (1993): "Montemolín. Evolución del asentamiento durante el Bronce Final y el Período Orientalizante (campañas de 1980 y 1981)", AAC 4: $15-48$.

BELÉN, Ma ${ }^{\text {; }}$ ANGLADA, R; ESCACENA, J.L.; JIMÉNEZ, A.; LINEROS, R. y RODRÍGUEZ, I. (1997): Arqueología en Carmona (Sevilla). Excavaciones en la Casa-Palacio del Marqués del Saltillo. Sevilla. 
BELÉN, Mª y ESCACENA, J.L. (1997): "Economía y sociedad en la Turdetania de los siglos V-IV a.C.", La Andalucía ibero-turdetana (siglos VI-IV a.C.). Huelva Arqueológica XIV: 137-160.

BELÉN, Ma .; ESCACENA, J.L. y BOZZINO, Mª.I. (1991): "Las comunidades prerromanas de Andalucía occidental", en M. Almagro-Gorbea y G. Ruiz Zapatero (eds.), Paleoetnología de la Península Ibérica. Complutum 2-3: 65-87.

CHAVES TRISTÁN, F. (1990): "Los hallazgos numismáticos y el desarrollo de la segunda guerra púnica en el sur de la Península Ibérica", Latomus XLIX, 3: 613-622.

CHAVES, F. y BANDERA, M.L. de la (1987): “Excavaciones arqueológicas en el cortijo de Vico", Anuario Arqueológico de Andalucía 1985 III: 372-379.

_- (1991): "Aspectos de la urbanística en Andalucía occidental en los ss. VII-VI a.C. a la luz del yacimiento de Montemolín (Marchena, Sevilla)", Atti del II Congresso Internazionale di Studi Fenici e Punici II: 691-714.

CHAVES, F.; BANDERA, Mª.L. de la; FERRER, E. y BERNÁLDEZ, E. (2000): “El complejo sacrificial de Montemolín", Actas del IV Congreso Internacional de Estudios Fenicios y Púnicos II: 573-581.

CHAVES, F.; BANDERA, Ma.L. de la; GARCÍA, E.; FERRER, E. y ORIA, M. (1993): "Montemolín 19801992", Investigaciones arqueológicas en Andalucía. Proyectos: 501-513. Huelva.

CORTIJO CEREZO, Mª.L. (1993): “Algunos aspectos sobre el medio rural en la Bética romana”, Hispania Antiqua XVII: $197-214$.

CURCHIN, L.A. (1985): "Vici and Pagi in Roman Spain", REA LXXXVII, 3-4: 327-342.

DOMÍNGUEZ, M.C.; CABRERA, P. y FERNÁNDEZ JURADO, F.J. (1988): “Cerro de la Cabeza (Santiponce, Sevilla)", NAH 30 (1988): 119-186.

ESCACENA CARRASCO, J.L. (1989): "Los turdetanos o la recuperación de la identidad perdida", en $\mathrm{M}^{\mathrm{a}}$.E. Aubet (dir.) Tartessos. Arqueología protohistórica del Bajo Guadalquivir: 433-476. Ed. Ausa. Sabadell.

- (1992): "Indicadores étnicos en la Andalucía prerromana", Spal 1: 321-343. (1993): "De la muerte de Tartesos. Evidencias en el registro poblacional", Spal 2: 183-218.

ESCACENA, J.L. y BELÉN, Mª . (1991): "Sobre la cronología del horizonte fundacional de los asentamientos tartésicos", Cuadernos del Suroeste 2: 9-42.

— (1997): "El poblamiento en la Baja Andalucía durante los siglos V y IV a.C.", La Andalucía iberoturdetana (siglos VI-IV a.C.). Huelva Arqueológica XIV: 31-60.

FERNÁNDEZ JURADO, J. (1987): Tejada La Vieja: una ciudad protohistórica. Huelva Arqueológica IX. Huelva.

FERRER ALBELDA, E. (1999a): "La olvidada 'necrópolis fenicia’ de Marchena (Sevilla)”, Spal 8: 101-114. _- (1999b): "La estela decorada de Montemayor (Córdoba)", Antiquitas 10: 65-71.

FERRER, E.; GARCÍA, E. y ORIA, M. (2000): "La Prospección Arqueológica Superficial del T.M. de Marchena y la conservación del Patrimonio Histórico", Actas de las V Jornadas sobre Historia de Marchena. El Patrimonio y su conservación: 75-103.

FERRER, E.; ORIA, M.; GARCÍA, E.; BANDERA, Mª.L. de la y CHAVES, F. (2001): "Informe de la Prospección Arqueológica Superficial de Urgencia del Término Municipal de Marchena (Sevilla)", AAA 1998 III: 1024-1038.

FERRER, E.; RUIZ; J.I. y GARCÍA, F.J. (2002): "Los orígenes de Osuna. Urso en el Bronce Final y en el período orientalizante", Urso. A la búsqueda de su pasado: 99-145. Osuna.

FRUTOS, G. de y MUÑOZ, A. (1996): "La industria pesquera y conservera púnico-gaditana: balance de la investigación. Nuevas perspectivas", Spal 5: 133-165.

GARCÍA FERNÁNDEZ, F.J. (e.p.): Los turdetanos en la Historia. Análisis de los testimonios literarios grecolatinos. Ed. Gráficas Sol. Écija. 
GARCÍA MORENO, L.A. (1989): “Turdetanos, túrdulos y tartesios. Una hipótesis", Estudios sobre la Antigüedad en homenaje al prof. S. Montero Díaz. Anejos de Gerión III: 289-294.

GARCÍA VARGAS, E.; MORA, M. y FERRER, E. (1989): "Estudios sobre cerámicas ibéricas andaluzas I: Montemolín”, Habis 20: 217-243.

GONZÁLEZ, J. (1996): Corpus de Inscripciones latinas de Andalucía. II. Sevilla, III: La campiña. Sevilla. GRACIA ALONSO, F. (1995): "Consideraciones sobre la estructura de los intercambios comerciales en la cultura ibérica", Verdolay 7: 177-185.

MURILLO REDONDO, J.F. (1994): La cultura tartésica en el Guadalquivir Medio. Ariadna 13-14. Palma del Río.

ORDÓÑEZ AGULLA, S. (1996): "La romanización en Marchena", Actas de las I Jornadas sobre Historia de Marchena: $37-72$.

PELLICER, M. (1978): “Tipología y cronología de las ánforas prerromanas del Guadalquivir según el Cerro Macareno (Sevilla)", Habis 9: 365-400.

(1982): "Ensayo de periodización y cronología tartesia y turdetana", Habis 10-11: 307-333. (1989): "El Bronce Reciente y los inicios del Hierro en Andalucía Occidental", en Ma. E. Aubet (coord.) Tartessos. Arqueología Protohistórica del Bajo Guadalquivir: 147-187. Ed. Ausa. Sabadell. (1992): "Problemática del Bronce e inicios del Hierro en Iberia", Paleoetnología de la Península Ibérica. Complutum 2-3: 11-18.

(1995): "Balance de 25 de años de investigación sobre Tartessos (1968-1993)", Tartessos 25 años después 1968-1993. Actas del Congreso Conmemorativo del V Symposium Internacional de Prehistoria Peninsular: 41-71. Jerez de la Frontera.

- (2000): "El proceso orientalizante en el Occidente ibérico", Huelva Arqueológica 16: 89-134.

PELLICER, M. y AMORES, F. (1985): "Protohistoria de Carmona. Los cortes estratigráficos CA-80/A y CA-80/B", NAH 22: 55-189.

PELLICER, M.; ESCACENA, J.L. y BENDALA, M. (1983): El Cerro Macareno. EAE 124. Ministerio de Cultura. Madrid.

RAMÓN TORRES, J. (1995): Las ánforas fenicio-púnicas del Mediterráneo central yoccidental. Col.lecció Instrumenta 2. Barcelona.

RUIZ MATA, D. (1987): "La formación de la cultura turdetana en la Bahía de Cádiz a través del Castillo de Doña Blanca", Iberos. Actas de las I Jornadas sobre el Mundo Ibérico: 299-314. Jaén.

RUIZ MATA, D. y PÉREZ, C.J. (1995): El poblado fenicio del castillo de Doña Blanca (El Puerto de Santa María, Cádiz). El Puerto de Santa María. 


\begin{tabular}{|c|c|c|c|c|}
\hline ESTRATOS & NIVELES & U.E. & PERÍODO & CRONOLOGÍA \\
\hline $\mathrm{I}$ & A-35 & cabaña & período orientalizante & h. 625 a.C. \\
\hline \multirow{4}{*}{ II } & A-34 & \multirow{4}{*}{ estrato } & \multirow{4}{*}{ período orientalizante } & \\
\hline & A-33 & & & \\
\hline & A-32 & & & \\
\hline & A-31 & & & \\
\hline \multirow{3}{*}{ III } & A-30 & \multirow{3}{*}{ estrato } & \multirow{3}{*}{ período orientalizante } & \multirow{3}{*}{ h. 600 a.C. } \\
\hline & A-29 & & & \\
\hline & A-28 & & & \\
\hline IV & A-27c & pavimento & período orientalizante & \\
\hline V & $A-27 b$ & estrato & período orientalizante & \\
\hline VI & A-27a & pavimento & período orientalizante & h. 550 a.C. \\
\hline VII & A-27 entre piedras & estrato & período orientalizante & \\
\hline VIIb & A-26 & estrato & período orientalizante & \\
\hline \multirow{2}{*}{ VIII } & A-25 & \multirow{2}{*}{ estrato } & \multirow{2}{*}{ período orientalizante } & \\
\hline & A-24 & & & \\
\hline IX & $A-23 b$ & pavimento & período turdetano & h. 500 a.C. \\
\hline $\mathrm{X}$ & A-23a & estrato & período turdetano & \\
\hline $\mathrm{XI}$ & A-22 & estrato & período turdetano & \\
\hline \multirow{2}{*}{ XII } & A-21 & \multirow[b]{2}{*}{ estrato } & \multirow[b]{2}{*}{ período turdetano } & \\
\hline & A-20 & & & \\
\hline XIII & $A-19 b$ & pavimento & período turdetano & \\
\hline XIV & A-19a & estrato & período turdetano & \\
\hline$X V$ & $A-18 b$ & pavimento & período turdetano & \\
\hline XVI & A-18a & estrato & período turdetano & h. 400 a.C. \\
\hline XVII & $A-18 n$ & estrato & período turdetano & \\
\hline XVIII & A-17s & estrato & período turdetano & \\
\hline \multirow{3}{*}{ XIX } & A-16 & \multirow{3}{*}{ estrato } & \multirow{3}{*}{ período turdetano } & \\
\hline & A-15 & & & \\
\hline & A-14 & & & \\
\hline \multirow{3}{*}{$X X$} & A-13 & \multirow{3}{*}{ estrato } & \multirow{3}{*}{ período turdetano } & \multirow{3}{*}{ h. 350 a.C. } \\
\hline & A-12s & & & \\
\hline & A-1ls & & & \\
\hline XXI & A-11 zanja de muro & estrato & período turdetano & \\
\hline \multirow{2}{*}{ XXII } & $A-12 n$ & \multirow{2}{*}{ estrato } & \multirow{2}{*}{ período turdetano } & \\
\hline & A-1 in & & & \\
\hline XXIII & A-10 & estrato & período turdetano & \\
\hline
\end{tabular}




\begin{tabular}{|c|c|c|c|c|}
\hline ESTRATOS & NIVELES & U.E. & PERÍODO & CRONOLOGÍA \\
\hline XXIV & $A-9 b$ & pavimento & período turdetano & h. 250 a.C. \\
\hline$X X V$ & A-9a & estrato & período turdetano & \\
\hline XXVI & A-9 & estrato & período turdetano & \\
\hline \multirow{2}{*}{ XXVU } & A-8 & \multirow{2}{*}{ estrato } & \multirow{2}{*}{ período turdetano } & \\
\hline & A-7 & & & \\
\hline \multirow{2}{*}{ XXVIII } & A-6 & \multirow{2}{*}{ estrato } & \multirow{2}{*}{ período turdetano } & \multirow{2}{*}{ h. 200 a.C. } \\
\hline & A-5 & & & \\
\hline \multirow{5}{*}{ XXIX } & A-4 & \multirow{5}{*}{ estrato } & \multirow{5}{*}{$\begin{array}{l}\text { período turdetano a } \\
\text { romano imperial }\end{array}$} & \\
\hline & A-3 & & & \\
\hline & A-2 & & & \\
\hline & A-1 & & & \\
\hline & A-su & & & \\
\hline
\end{tabular}

